\title{
Fault-controlled dolomitization in the Montagna dei Fiori Anticline (Central Apennines, Italy): record of a dominantly pre-orogenic fluid migration
}

\author{
Mahtab Mozafari ${ }^{1}$, Rudy Swennen ${ }^{2}$, Fabrizio Balsamo ${ }^{1}$, Hamdy El Desouky ${ }^{2,3}$, Fabrizio Storti $^{1}$, and \\ Conxita Taberner ${ }^{4}$ \\ ${ }^{1}$ NEXT - Natural and Experimental Tectonics Research Group - Department of Chemistry, Life Sciences \\ and Environmental Sustainability, University of Parma, Italy \\ ${ }^{2}$ Department of Earth and Environmental Sciences, KU Leuven, Leuven, Belgium \\ ${ }^{3}$ Geology Department, Faculty of Science, Menoufia University, Menoufia, Egypt \\ ${ }^{4}$ Shell Global Solutions International B.V., Amsterdam, the Netherlands
}

Correspondence: Mahtab Mozafari (mahtab_mozafari@yahoo.com)

Received: 15 December 2018 - Discussion started: 3 January 2019

Revised: 26 May 2019 - Accepted: 17 July 2019 - Published: 20 August 2019

\begin{abstract}
The Lower Jurassic platform and basinal deposits exposed in the Montagna dei Fiori Anticline (Central Apennines, Italy) are pervasively affected by dolomitization. Based on the integration of field work, petrography, and geochemistry, two fault-related dolomitization events were recognized and interpreted as having occurred before and during the Apenninic orogeny. Fluid inclusion analysis indicates moderate to elevated salinity values of 3.5 to 20.5 and 12.8 to 18.6 eq. wt $\% \mathrm{NaCl}$ in the first and the second event, respectively. The estimated salinities, in combination with $\delta^{18} \mathrm{O}$ values and ${ }^{87} \mathrm{Sr} /{ }^{86} \mathrm{Sr}$ ratios, suggest significant involvement of evaporitic fluids in both events, most likely derived from the underlying Upper Triassic Burano Formation. In addition, the ${ }^{87} \mathrm{Sr} /{ }^{86} \mathrm{Sr}$ ratios up to 0.70963 suggest the circulation of deep-sourced fluids that interacted with siliciclastic rocks and/or the crystalline basement during the dolomitization events.

Two major dolomite types (D1 and D2) were recognized as pertaining to the first event, both postdated by highamplitude bed-parallel stylolites, supporting a syn-burial prelayer-parallel shortening dolomitization. A possible geodynamic framework for this dolomitization event is Early Jurassic to Late Jurassic rift-related extensional tectonism. The second dolomitization event (D3, D4, and D5) is characterized by a temperature upturn (up to $105^{\circ} \mathrm{C}$ ) and interpreted as associated with the inflow of hydrothermal fluids, possibly related to major changes in the permeability archi-
\end{abstract}

tecture of faults during early- to syn-thrusting and folding activity. Based on the timing of deformation in the Montagna dei Fiori Anticline, the second dolomitization event likely occurred in Late Miocene to Pliocene times. The findings regarding characteristics and timing of dolomitization here illustrates the long-term controlling role of the evaporitic detachments in the dolomitization process. This study shows that the Mg-rich fluids that were most likely derived from evaporites may prime the tectonically involved successions for repeated dolomitization, and hence the formation of potential reservoirs during sequential tectonic modifications (extensional vs. compressional).

\section{Introduction}

Fault-controlled dolomitization has been the focus of attention in many studies during the last decades due to its influential role in modifying the petrophysical properties of rocks, and hence anisotropy, in fluid migration pathways, and ultimately on reservoir quality (e.g., Purser et al., 1994; Montanez, 1994; Zempolich and Hardie, 1997; Vandeginste et al., 2005; Davies and Smith, 2006; Sharp et al., 2010). The mechanical and hydrological behavior of fault zones are in turn influenced by fluid-rock interactions and diagenetic modifications (e.g., Gale et al., 2004; Laubach et al., 2010; 
Clemenzi et al., 2015; Ferraro et al., 2019). It follows that the mutual interplay between fault activity and fluid-rock interaction can trigger dolomitization of carbonates when exposing to Mg-saturated or oversaturated fluids and, consequently, variations in physicochemical properties of fluids through time and space.

Leaking or sealing behaviors of fault zones during deformation are key controls for fault-related fluid circulation. A detailed understanding of such an interplay is thus necessary to improve our capability of making reliable predictions of fault-related dolomitization in carbonate reservoirs. Studying outcrop analogs provides fundamental support to meet this requirement and the opportunity to assess the spatial distribution of dolomitized zones, and individual diagenetic events, in 3-D (e.g., Swennen et al., 2012; Dewit et al., 2014; Bistacchi et al., 2015).

The Lower Jurassic to Lower Cretaceous Umbria-Marche passive margin carbonate succession, in the Central Apennines (Italy), is intensely affected by localized dolomitization both in the onshore fold-and-thrust belt and in the offshore foredeep and foreland areas (e.g., Murgia et al., 2004; Pierantoni et al., 2013). The dolomitized intervals which are the focus of this study are well exposed in the core of the Montagna dei Fiori Anticline, where the dolomitized Lower Jurassic intervals (Calcare Massiccio, Bugarone, and Corniola formations) and their relationships with fault zones allow us to study the mutual influence between deformation structures and dolomitized intervals (Fig. 1). These intervals, known as the Castel Manfrino dolostones (Crescenti, 1969; Mattei, 1987; Koopman, 1983), have been previously studied by Ronchi et al. (2003) only at its reference section, exposed at the Castel Manfrino location (Fig. 1b) in the central sector of the Montagna dei Fiori Anticline (Fig. 2). A fault-controlled dolomitization model and the relative timing of dolomitization were proposed by the latter authors based on the homogenization temperatures obtained from microthermometry of the fluid inclusions, and their relation with the thermal history of the area studied. However, no clear relation between dolomitization and structural evolution of the Montagna dei Fiori Anticline on a local scale was provided to confidently link the occurrence of dolomitization to a particular tectonic event. Moreover, the nature and origin of the dolomitizing fluids were not well constrained. Recent reevaluation of dolostone distribution in the Montagna dei Fiori Anticline (Storti et al., 2017a) showed that the dimension of the dolomitized geobodies (Fig. 2) is much more significant than what was previously mapped by Mattei (1987). Dolostones are distributed within fault damage zones and in the laterally adjacent carbonate rocks, and in intersection areas between fault sets, for a total area in map view of more than $1.5 \mathrm{~km}^{2}$ (Storti et al., 2017a).

The structural pattern of the Montagna dei Fiori Anticline documents the overprinting of extensional and contractional deformation along major fault zones. The preserved structural framework in this anticline provides an opportunity to study the direct but complex regional tectonic controls on dolomitization in carbonate successions undergoing multiple deformation events, from rifting to folding and thrusting. This contribution integrates new petrographic, geochemical, and microthermometric analyses with structural studies (Storti et al., 2018) to characterize the temporal record of fault-controlled diagenetic phases and, more specifically, dolomitization in the carbonatic succession outcropping in the Montagna dei Fiori Anticline. These findings might be of relevance for exploration and reservoir quality prediction in the region of the Apennines and the Southern Alps, both onshore and offshore. Moreover, this work provides additional evidence of the potential influence of fluids derived from evaporitic detachment levels in modifications of geochemical trends and petrophysical properties of the overlying carbonate rocks.

\section{Geological setting}

The Montagna dei Fiori Anticline is a NNW-SSE-striking thrust-related fold located at the mountain front of the Central Apennines (Fig. 1). The geodynamic evolution of the Apennines has been proposed to be the result of the superposition of NE-SW compression (in present-day geographic coordinates), related to the convergence of the Eurasian and African plates since Late Cretaceous times (Elter et al., 1975; Dewey et al., 1989; Patacca et al., 1992), on a rifting-related tectonosedimentary architecture produced by Early Jurassic extension (e.g., Centamore et al., 1971). In such a framework, the Central Apennines developed during Miocene to "PlioPleistocene" times (e.g., Parotto and Praturlon, 1975; Barchi et al., 1998; Mazzoli et al., 2002; Bollati et al., 2012).

The Central Apennines involves the Umbria-Marche succession, which essentially includes Triassic to Miocene carbonates and marls, covered by Miocene to Pliocene synorogenic clastic sediments (Fig. 1). The pre-orogenic succession, from bottom to top, includes Late Triassic evaporites, dolomites, and limestones of the Burano Formation, which the basal detachment runs within its evaporitic interval (Ghisetti and Vezzani, 2000); Early Jurassic to Late Jurassic platform and basinal limestones and dolostones (Calcare Massiccio, Corniola, Rosso Ammonitico, Calcari a Posidonia, and Calcari ad Aptici formations); and Cretaceous to Early Miocene basinal carbonates (Maiolica, Marne a Fucoidi, Scaglia, and Biscaro formations). In general, the lower part of the Burano Formation is overlaid by the fluvio-deltaic siliciclastic rocks of the Verrucano Formation (Middle Triassic to Late Triassic) (Tongiorgi et al., 1977; Ghisetti and Vezzani, 2000; Tavani et al., 2008). Nevertheless, the existence of these siliciclastic rocks in the Montagna dei Fiori area is not yet proven. Syn-orogenic deposits include Miocene marls and turbiditic sandstones (Marne con Cerrogna and Laga formations) (Artoni, 2013, and references therein). 


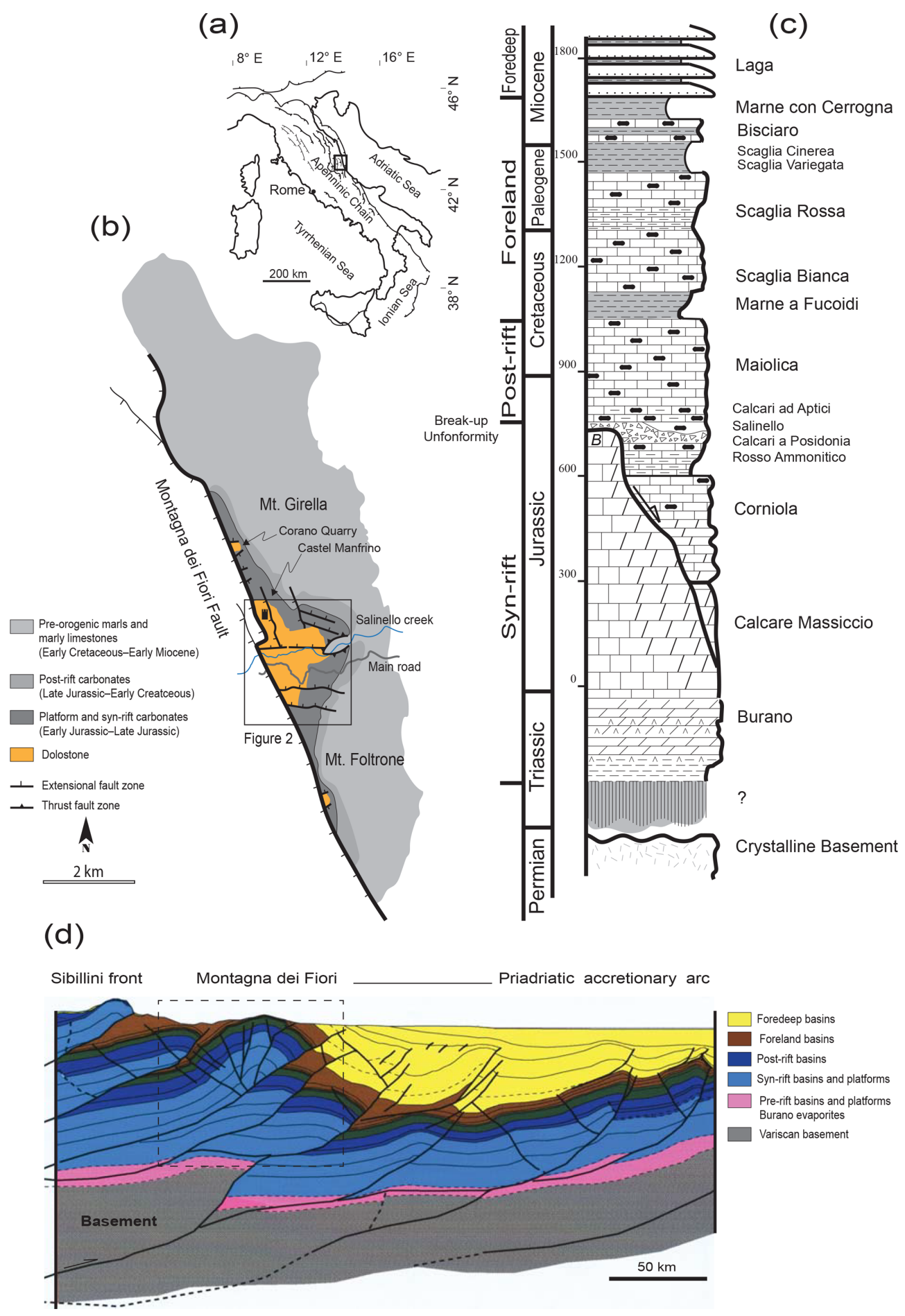

Figure 1. (a) Simplified regional map (modified after Ghisetti and Vezzani, 1997) showing the tectonic outlines of the Central Apennines and the study area (rectangle). (b) Schematic geological map of the Montagna dei Fiori Anticline showing the distribution of dolostones (modified after Storti et al., 2017a). (c) Lithostratigraphical column of the successions exposed in Montagna dei Fiori (modified after Mattei, 1987; Di Francesco et al., 2010; Storti et al., 2018). Letter B stands for the Bugarone Formation. Lithologies are mentioned in the text. Note that the thickness of the non-outcropping formations (Triassic evaporites and the crystalline basement) is not to scale. (d) Regional geological transect across present-day Central Apennines and the Adriatic Sea (modified after Fantoni and Franciosi, 2010) with vertical exaggeration of $2: 1$. The dashed rectangle indicates the Montagna dei Fiori Anticline region. 


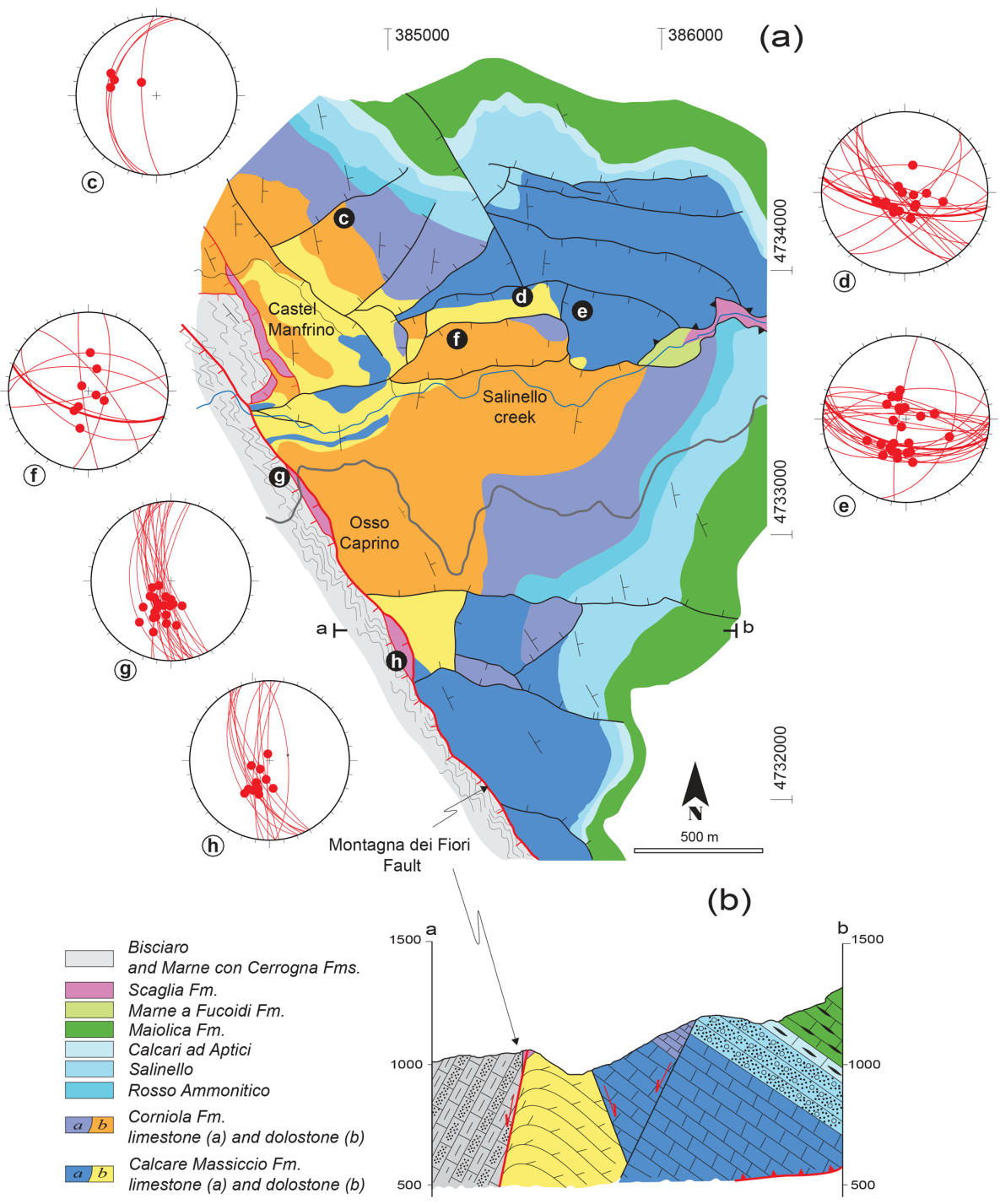

Figure 2. $(\mathbf{a}, \mathbf{b})$ Geological map of the central sector of the Montagna dei Fiori Anticline and cross section oriented parallel (a-b) to the hinge line representing the tectonostratigraphic architecture of the faulted anticline (modified after Storti et al., 2017a). The stereonets (Schmidt equal area projection lower hemisphere) provide the attitude of the extensional faults. The locations of the corresponding field sites are indicated by letters. (c) At this location, well exposed N-S-striking extensional fault zones offset the dolomitized Corniola Formation. The fault zone is characterized by near-horizontal stylolites localized in the footwall damage zone (4 fault data). (d, e, and f) These locations consist of mostly $\sim$ E-W-striking extensional fault zones. Particularly the boundary fault zones delimiting Calcare Massiccio Formation in the main horst block is evident (site d: 20 fault data; site e: 24 fault data; site f: 9 fault data). ( $\mathrm{g}$ and $\mathrm{h}$ ) At these locations, dip-slip slickenlines support major extensional movements related to the Montagna dei Fiori Fault. Contractional deformation structures are preserved in the bed-perpendicular stylolites, shear surfaces, and tension gashes arranged as S-C arrays (site g: 21 fault data; site h: 14 fault data). Equal area projection, lower hemisphere.

The deposition of the Calcare Massiccio Formation (Hettangian to Sinemurian), with a total thickness varying between 300 and $700 \mathrm{~m}$ (Pialli, 1971), records an important extension pulse in the evolution of Tethyan rifting. The lower part of this formation, which was interpreted as having been deposited in a peritidal environment, consists of peloidal pack- to grainstones in alternation with peloidal wacke- to packstones including horizons of algal bindstones (Calcare Massiccio A; Brandano et al., 2016). The upper part is made up of beds of skeletal and coated grain wacke- to grainstones (Calcare Massiccio B; Brandano et al., 2016). It corresponds to lower to middle shelf depositional environments, characterized by a general deepening-upward trend. Overall, the Early Jurassic rifting led to the growth of the Calcare Massiccio Formation in a carbonate platform setting, followed by faulting and drowning, and development of pelagic intrabasins filled by syn-rift sediments (Fig. 1c; Bernoulli et al., 1979; Santantonio and Carminati, 2011). The syn-rift 
sediments include pelagic limestones of the Bugarone and Corniola formations. Condensed pelagic limestones of the Bugarone Formation (Lower Pliensbachian to Lower Tithonian; "Bugarone Group" in Pierantoni et al., 2013) occur at the top of the Calcare Massiccio Formation where it formed fault-controlled highs marking the regional drowning of the carbonate platform (Santantonio and Carminati, 2011). The pelagic limestones of the Corniola Formation (Sinemurian to Toarcian; Colacicchi et al., 1975; Morettini et al., 2002; Bosence et al., 2009; Marino and Santantonio, 2010; Brandano et al., 2016) occur within the fault-controlled (half)grabens in lateral continuation with the Calcare Massiccio Formation. The Corniola Formation in the lower part consists of turbiditic lobes which originated from tectonic brecciation of the Calcare Massiccio Formation. The upper part consists of a well-bedded pelagic mudstone with chert nodules (Di Francesco et al., 2010).

\section{Structural framework}

The Montagna dei Fiori Anticline is intersected by two major fault categories (Storti et al., 2018), which based on the chronological order include the following. Firstly, $\sim$ E-Wand $\sim \mathrm{N}-\mathrm{S}$-striking fault zones showing extensional kinematics bounding the major outcrops of Calcare Massiccio and dominantly affecting the Jurassic rocks older than the Maiolica Formation (Fig. 2a; e.g., sites 1 to 4). Overprinting relations indicate that $\sim \mathrm{E}-\mathrm{W}$ deformation structures are systematically younger than the $\sim \mathrm{N}-\mathrm{S}$ ones. Similar trends were observed in syn-rift fault zones in other anticlines of the Central Apennines (e.g., Cooper and Burbi, 1986; Alvarez, 1989; Chilovi et al., 2002). Such a tectonosedimentary inheritance was involved in the growth of the Montagna dei Fiori Anticline, which initiated during the Late Miocene (Mazzoli et al., 2002; Artoni, 2003) and progressively evolved into the upper thrust sheet of a well-developed antiformal stack until Plio-Pleistocene times (e.g., Mazzoli et al., 2002; Calamita et al., 1994; Artoni, 2013). The second set of faults is a major structural feature trending parallel to the Montagna dei Fiori Anticline and dissecting it is the Montagna dei Fiori Fault, a NNW-SSE-striking extensional fault system cutting at a high angle through the folded footwall rocks, typically at the forelimb-crest transition (Figs. 1,2). This fault consists of two partially overlapping main fault zones with an extensional stratigraphic separation exceeding $900 \mathrm{~m}$, and juxtaposes intensely deformed Late Miocene sediments in the hanging wall against dolomitized and undolomitized Lower Jurassic and Cretaceous limestones in the footwall (Figs. 1 and 2). The development of the Montagna dei Fiori Fault has been alternatively interpreted as either a pre-folding (e.g., Calamita et al., 1994; Mazzoli et al., 2002; Scisciani et al., 2002) or late-folding (Ghisetti and Vezzani, 2000) feature. More recently, the origin of the Montagna dei Fiori Fault has been ascribed to the mutual interaction between horizontal shortening and uplift and episodic gravitational re- equilibration during antiformal stacking underneath the anticline during Plio-Pleistocene times (Storti et al., 2018). The dolomitized intervals are exposed in the damage zones of both aforementioned fault categories.

\section{Methodology}

The fieldwork covered an area of over $4 \mathrm{~km}^{2}$ to delineate the distribution of dolostones. The stratigraphic and deformational features of dolostones were analyzed in more than 60 outcrops. The distribution of dolomitized intervals as well as their cross-cutting relationships with bedding planes, stylolites, veins, and faults was documented and sampled. For petrographic analyses, 130 polished thin sections were studied with standard petrographic methods (transmitted and UVfluorescent light microscopy). Dolomite crystal morphology and texture is based on the classification proposed by Sibley and Gregg (1987).

The rock slabs and thin sections were stained using Alizarine Red S and potassium ferricyanide (Dickson, 1966) to discriminate dolomite from calcite and evaluate their iron content. Cold-cathode cathodoluminescence (CL) microscopy was carried out on representative thin sections $(n=$ 80) at KU Leuven university (Belgium) using a Technosyn cathodoluminescence device $(8-15 \mathrm{kV}, 200-400 \mu \mathrm{A}$ gun current, 0.05 Torr vacuum, and $5 \mathrm{~mm}$ beam width).

$\delta^{13} \mathrm{C}$ and $\delta^{18} \mathrm{O}$ analysis were carried out on 117 samples. To ensure the sampling quality and avoid physical mixing of different diagenetic phases, the thin section images were mapped and the sampling targets were determined. Nevertheless, some diagenetic phases could not be isolated due to their sequential overgrowth and small size. Powder samples (150$200 \mu \mathrm{g}$ ) were obtained by applying a New Wave Research micromilling device and a dental drill at KU Leuven university (Belgium). The analysis was conducted at Parma University (Italy) and the Friedrich-Alexander-Universität (ErlangenNürnberg, Germany) laboratories using Finnigan DeltaPlus $\mathrm{V}$ and Thermo Finnigan 252 mass spectrometers, respectively. The carbonate powders were reacted with $100 \%$ phosphoric acid at constant temperature of $75^{\circ} \mathrm{C}$. Several additional $\mathrm{CO}_{2}$ reference gases (NBS18, NBS19, MAB99, and a pure Carrara marble) with known isotopic ratios were analyzed during the measurements to determine the $\delta^{13} \mathrm{C}$ and $\delta^{18} \mathrm{O}$ values of the sample. Reproducibility was checked by replicate analysis of laboratory standards and was better than $\pm 0.1 \%$ for $\delta^{13} \mathrm{C}$ and $\pm 0.2 \%$ of $\delta^{18} \mathrm{O}$ at Parma University and \pm 0.04 for $\delta^{13} \mathrm{C}$ and $\pm 0.05 \%$ for $\delta^{18} \mathrm{O}$ at Friedrich-Alexander-Universität. Oxygen isotope composition of dolomites was corrected using the acid fractionation factors given by Rosenbaum and Sheppard (1986). Duplicate homogeneous samples were measured in both labs for interlaboratory reproducibility. All carbon and oxygen values are reported in per mill, relative to the Vienna Pee Dee Belemnite (V-PDB). 
A total number of 21 samples were analyzed for their ${ }^{87} \mathrm{Sr} /{ }^{86} \mathrm{Sr}$ ratios. The analyses were conducted at the Department of Analytical Chemistry, Ghent University (Belgium) and at the Vrije Universiteit Amsterdam (the Netherlands). NIST SRM 987 was used as the international Sr standard in both labs. At Ghent University, 15 sample powders $(20 \mathrm{mg})$ were collected using a dental drill device. The ${ }^{87} \mathrm{Sr} /{ }^{86} \mathrm{Sr}$ ratio measurements were performed using a Thermo Scientific Neptune multi-collector inductively coupled plasma mass spectrometer (MC-ICP-MS) instrument. Within the external precision, repeated analyses of the international $\mathrm{Sr}$ standard yielded an average ${ }^{87} \mathrm{Sr} /{ }^{86} \mathrm{Sr}$ ratio of $0.710271 \pm 0.000023$ ( $2 \mathrm{SD}, n=43$ ), in agreement with the accepted ${ }^{87} \mathrm{Sr} /{ }^{86} \mathrm{Sr}$ ratio of 0.710248 for this reference sample (Thirlwall, 1991). At Vrije Universiteit Amsterdam, six sample powders (2-3 mg) were collected using a New Wave Research micromilling device. Analyses were performed using a Thermo Electron Triton plus thermal ionization mass spectrometry (TIMS) instrument. In order to monitor and document the system's performance, repeated analyses of the international $\mathrm{Sr}$ standard $(n=58)$ were carried out on load sizes of 10 and $100 \mathrm{ng}$ which yielded average ${ }^{87} \mathrm{Sr} /{ }^{86} \mathrm{Sr}$ ratios of $0.710245 \pm 0.000022$ (2SD) and $0.710242 \pm 0.000008$ (2SD), respectively. In both labs mass discrimination correction was performed via internal normalization using Russell's exponential law and the accepted value (0.1194; Steiger and Jager, 1977) of the invariant ${ }^{86} \mathrm{Sr} /{ }^{88} \mathrm{Sr}$ ratio.

Fluid inclusion microthermometry analysis was performed on 11 doubly polished wafers $(80-130 \mu \mathrm{m}$ in thickness). Measurements were carried out at Parma University (Italy) using Linkam THMSG-600 and Linkam MDS-600 heatingcooling stages coupled with a Leica DM 2500 microscope. The final melt $\left(\mathrm{Tm}_{\mathrm{ice}}\right)$ and homogenization temperatures $\left(T_{\mathrm{h}}\right)$ were reproducible within 0.5 and $5{ }^{\circ} \mathrm{C}$, respectively. The stages were calibrated by synthetic Syn Flinc ${ }^{\mathrm{TM}}$ fluid inclusion standards. A $100 \times$ objective was used during the microthermometry runs of the small inclusions. The microthermometry data were collected following the fluid inclusion assemblage (FIA) approach described in Goldstein and Reynolds (1994) for carbonate minerals. The inconsistent homogenization temperatures and salinities obtained for these fluid inclusions, within the framework of an individual fluid inclusion assemblage (FIA) described by Goldstein and Reynolds (1994), indicate possible re-equilibration (stretched) of these inclusions and thus are not used in the interpretations. It is common for small inclusions $(<3 \mu \mathrm{m})$ to remain in an all-liquid monophase at room temperature due to their metastability (Goldstein and Reynolds, 1994). Thus, to eliminate the possible role of metastability, the samples were placed in a freezer for several days following the procedures described in detail by Goldstein and Reynolds (1994). All-liquid inclusions remained unchanged and no vapor bubble was developed within them, which discards the metastability effect. In order to properly observe the phase transitions and determine the final melting temperature of ice in the all-liquid inclusions, they were rapidly heated up to $\sim 200^{\circ} \mathrm{C}$ to stretch and nucleate a bubble at room temperature (Goldstein, 1990). The salinities are reported in equivalent weight percent $\mathrm{NaCl}$ (eq. wt $\% \mathrm{NaCl}$ ) and were calculated based on the equation of Bodnar (1993). The homogenization temperatures obtained in all-fluid inclusion assemblages indicate the minimum temperatures at which the fluids could have been trapped (Goldstein and Reynolds, 1994). No correction was made for pressure effects on entrapment temperatures since no data regarding the exact depth and pressure of entrapment are available. In the absence of independent thermal indicators such as the Conodont Alteration Index (CIA) and vitrinite reflectance (VR), the accuracy of pressure correction cannot be well constrained (Slobodník et al., 2006), and thus no correction was made for pressure effects on homogenization temperatures.

In order to perform high-resolution petrography, scanning electron microscope (SEM) and back-scattered scanning electron microscope (BSEM) analyses were conducted using a JEOL 6400 scanning electron microscope (SEM) equipped with an Oxford EDS (energy dispersive system). Operating conditions were $15 \mathrm{kV}$ and $1.2 \mathrm{nA}$, electron beam about $1 \mu \mathrm{m}$ in diameter, and $100 \mathrm{~s}$ counting time; errors are $\pm 2 \%-5 \%$ for major elements and $\pm 5 \%-10 \%$ for minor components. The analysis focused mainly on detecting possible dolomite crystals inside the bed-perpendicular stylolites affecting the Cretaceous Scaglia Formation.

\section{Results}

\subsection{Field observation and distribution of the dolomitized bodies}

There is no evidence of dolomitization in the overlying and immediate surrounding successions of the Calcare Massiccio, Bugarone, and Corniola formations (e.g., Maiolica and Scaglia formations), though the base of Maiolica Formation is reported as dolomitized in the Central Apennines onshore (e.g., Pierantoni et al., 2013) and offshore areas (Murgia et al., 2004).

Dolomitized intervals are folded in the forelimb of the Montagna dei Fiori Anticline and are abruptly truncated by the Montagna dei Fiori Fault, which juxtaposes them against intensely foliated Scaglia, Bisciaro, and Marne con Cerrogna formations (Figs. 2 and 3). The distribution of dolomitized intervals is wider in the Salinello creek (Figs. 1b, 2a), perhaps due to a better exposure. In the Corano Quarry location, dolomitization occur in the Calcare Massiccio and Bugarone formations only as meter-sized dolostone geobodies in the footwall of the Montagna dei Fiori Fault (Fig. 4). The map pattern (Fig. 2) of dolostones indicates that their distribution is maximized in the Castel Manfrino to Osso Caprino hill area and fades out both southward and eastward. 


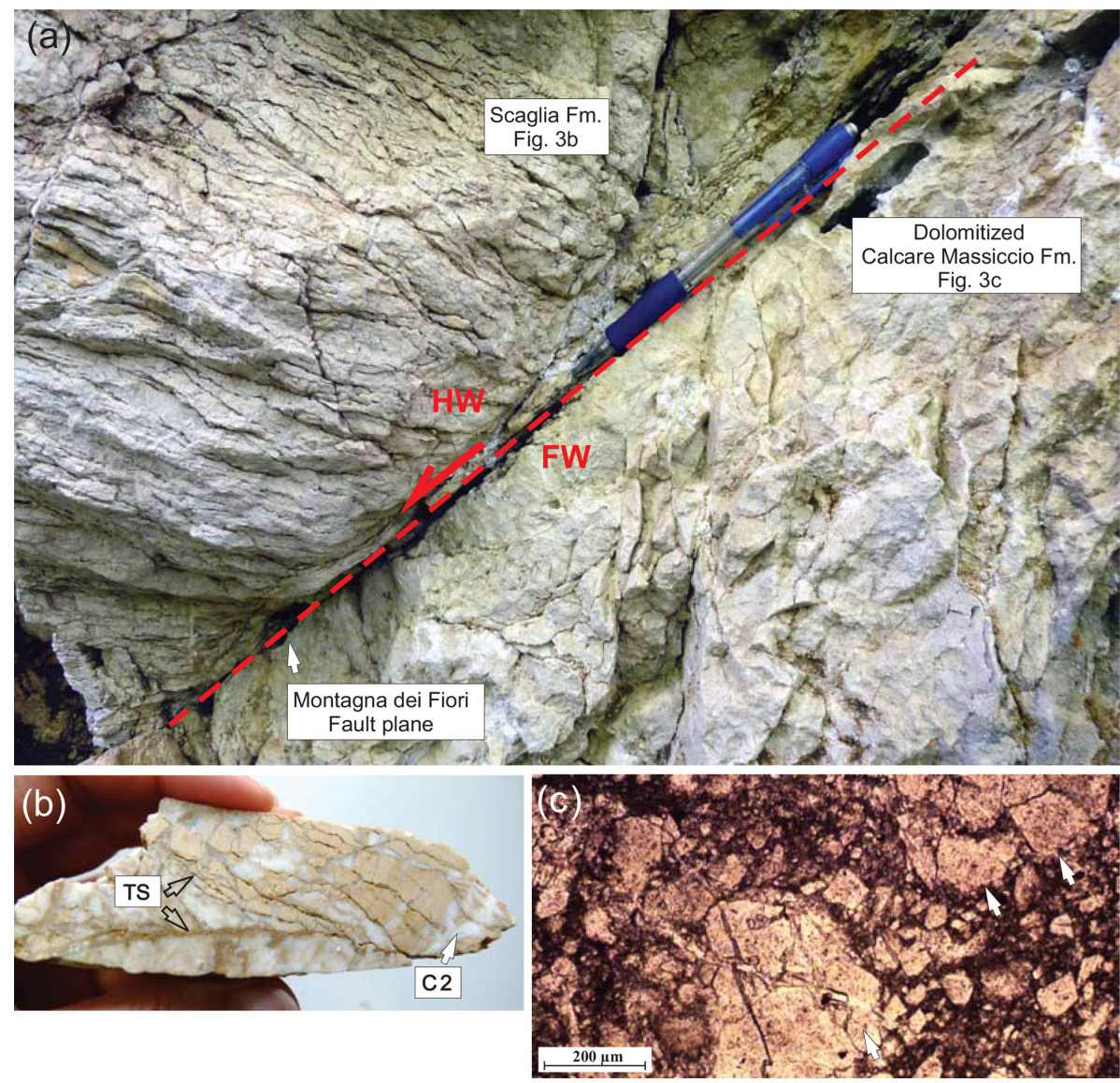

Figure 3. (a) Field photograph showing the deformed Scaglia Formation in the hanging wall (HW) and brecciated, dolomitized Calcare Massiccio Formation in the footwall (FW) of the Montagna dei Fiori Fault. The red arrow indicates the sense of fault movement. (b) A hand specimen from the deformed Scaglia Formation showing abundant pressure solution seems (TS), indicated by arrows, cross-cutting calcite veins (C2). (c) A transmitted light photomicrograph of the dolomitized, brecciated Calcare Massiccio Formation. Note all the breccia fragments are composed of dolomite (D4 here).

The lateral extent of dolomitization is gradual. In some outcrops, dolomitization fronts show irregular outlines following, but also cross-cutting, bedding surfaces (Fig. 5). Dolomitized intervals vary in thickness from a few meters to hundreds of meters affecting the totality of the exposed Calcare Massiccio and the lower part of Corniola Formation, where no clay interlayers are present. In the Calcare Massiccio Formation, dolomitization does not follow a systematic pattern. In the northern side of the Osso Caprino hill (Fig. 2), the top of formation is dolomitized but moving toward the Salinello creek and a thick non-dolomitized limestone is exposed. The same situation occurs on the opposite side of the creek and to the east of Castel Manfrino.

Dolomitized intervals in the Corniola Formation have a darker color relative to the host rock and are systematically more fractured than the hosting limestone. High-amplitude $(>1 \mathrm{~mm})$ bed-parallel stylolites are clearly visible in both limestones and dolostones (Fig. 5). However, in some dolostones only ghosts of stylolite traces can be seen. No apparent porosity could be observed in host rock limestones but the dolostones locally contain porosity, appearing as millimeter- to centimeter-sized pores. Dolostone breccias in fault cores are typically clast supported, with angular and millimeter- to centimeter-sized fragments (Fig. 3c), changing to crackle breccia (Woodcock and Mort, 2008) away from the main slip surface. In the proximity of the main slip surface, dolostone fragments are sporadically cross-cut by millimeter-sized dolomite veins. The breccia fragments, where cemented, are commonly surrounded by calcite cement.

\subsection{Petrography}

\subsubsection{Early calcite cementation}

The early diagenetic products in the studied intervals are generally nonferroan calcite cements. The first calcite cements precipitated following a phase of bioclast micritization (sensu Bathurst, 1975) in grain-supported intervals. In chronological order they include the following: (1) fibrous 


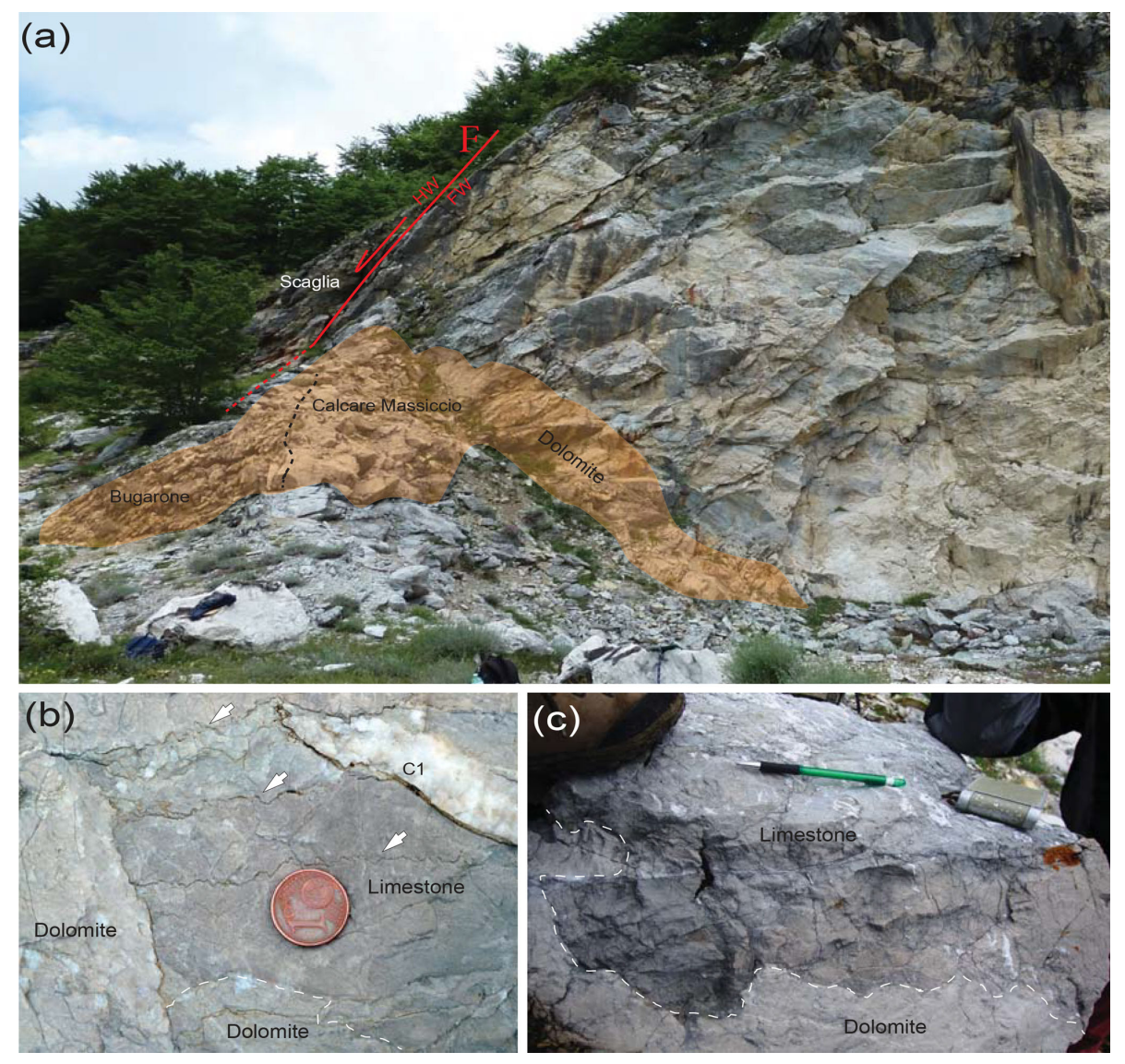

Figure 4. Field photographs (Corano Quarry) showing the field relations between dolostones (only D3 here), host limestones, and the Montagna dei Fiori Fault. (a) Panoramic view showing the spatial relationship between limestones and dolostones (orange) in the damage zone of the Montagna dei Fiori Fault (F). Note that the limestones and including dolostones of the Calcare Massiccio and Bugarone formations on the footwall (FW) and marly limestones of the Scaglia Formation on the hanging wall (HW) are intensely deformed. (b) Plan view of the dolomitized Calcare Massiccio limestone in the footwall damage zone, intersected by calcite veins $(\mathrm{C} 1)$ which are partially dolomitized and affected by bed-perpendicular stylolites (arrows). (c) Distinct transition (dashed line) between dolomitized and undolomitized Calcare Massiccio limestone in the footwall damage zone.

cements (FC) riming the bioclasts, mostly in the peloidal facies of the Calcare Massiccio Formation (Fig. 6a). These cements are dark-brown to non-luminescent under cathodoluminescence; (2) mosaic cements (MC) commonly fill the intergranular pore spaces (Fig. 6b) and also occur as syntaxial overgrowths on echinoderm fragments. They exhibit deformation twinning and show a well-developed brown and orange concentrically zoned cathodoluminescence pattern (Fig. 6c and d). They contain only monophase all-liquid inclusions. All of these cements are postdated by dolomites and high-amplitude bed-parallel stylolites (Fig. 6b).

\subsubsection{Dolomitization}

All the dolomite types are nonferroan and dominantly fabric destructive. Dolomitization developed in all the facies types of the Calcare Massiccio and the overlaying Bugarone formations, but only at the lower part of the Corniola Formation which consists of resedimented Calcare Massiccio breccias (turbiditic lobes).

The two first dolomite types (D1 and D2) are the dominant dolomite types in the studied outcrops. These dolomites are distributed within the damage zones of the $\sim \mathrm{N}-\mathrm{S}$ and $\mathrm{E}-$ W Jurassic rift-related extensional faults and, in places, displaced by them (Fig. 2a, site 1). The third and fourth dolomite types (D3 and D4) are mainly observed within the damage zone of the Montagna dei Fiori Fault (NNW-SSE) and appear only as dolomitic pockets locally replacing the host rock and overgrowing D1 and D2 at the proximity of the $\sim \mathrm{N}-\mathrm{S}$ and $\mathrm{E}-\mathrm{W}$ extensional faults. The fifth dolomite type (D5) is found only within the brecciated zones associated with the Montagna dei Fiori Fault damage zone. The distinctive petrographic features of the recognized dolomite types are summarized below:

Dolomite 1 (D1) is a replacive dolomite which commonly appears as dispersed rhombs and aggregates, and locally 

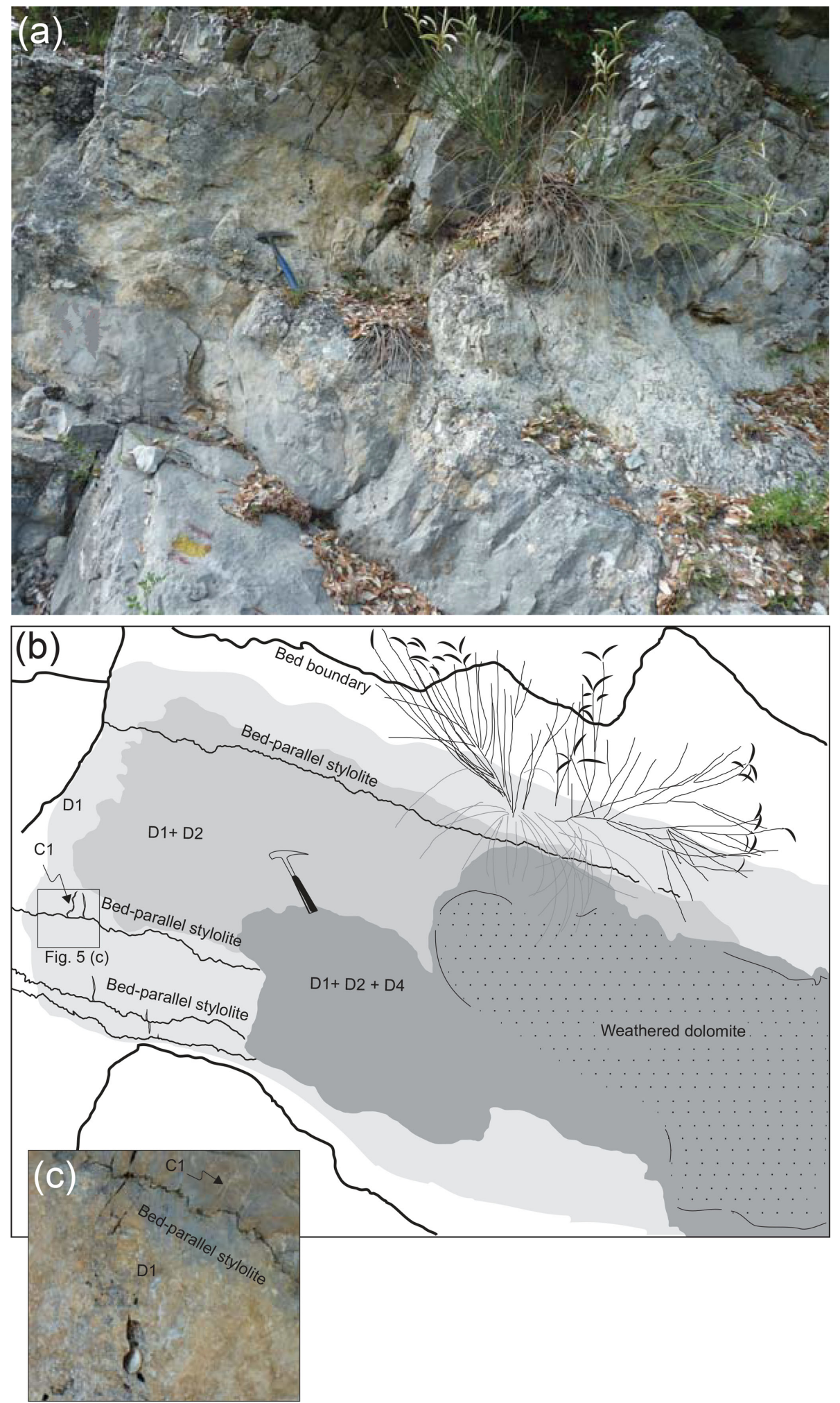

Figure 5. Field photograph (a) and a simplified sketch (b) of field site d showing a dolomitic pocket (grey color) and its relation with bed-parallel stylolites within the Calcare Massiccio Formation (hammer is $40 \mathrm{~cm}$ long). Note $\mathrm{C} 1$ is the only calcite cement here. 

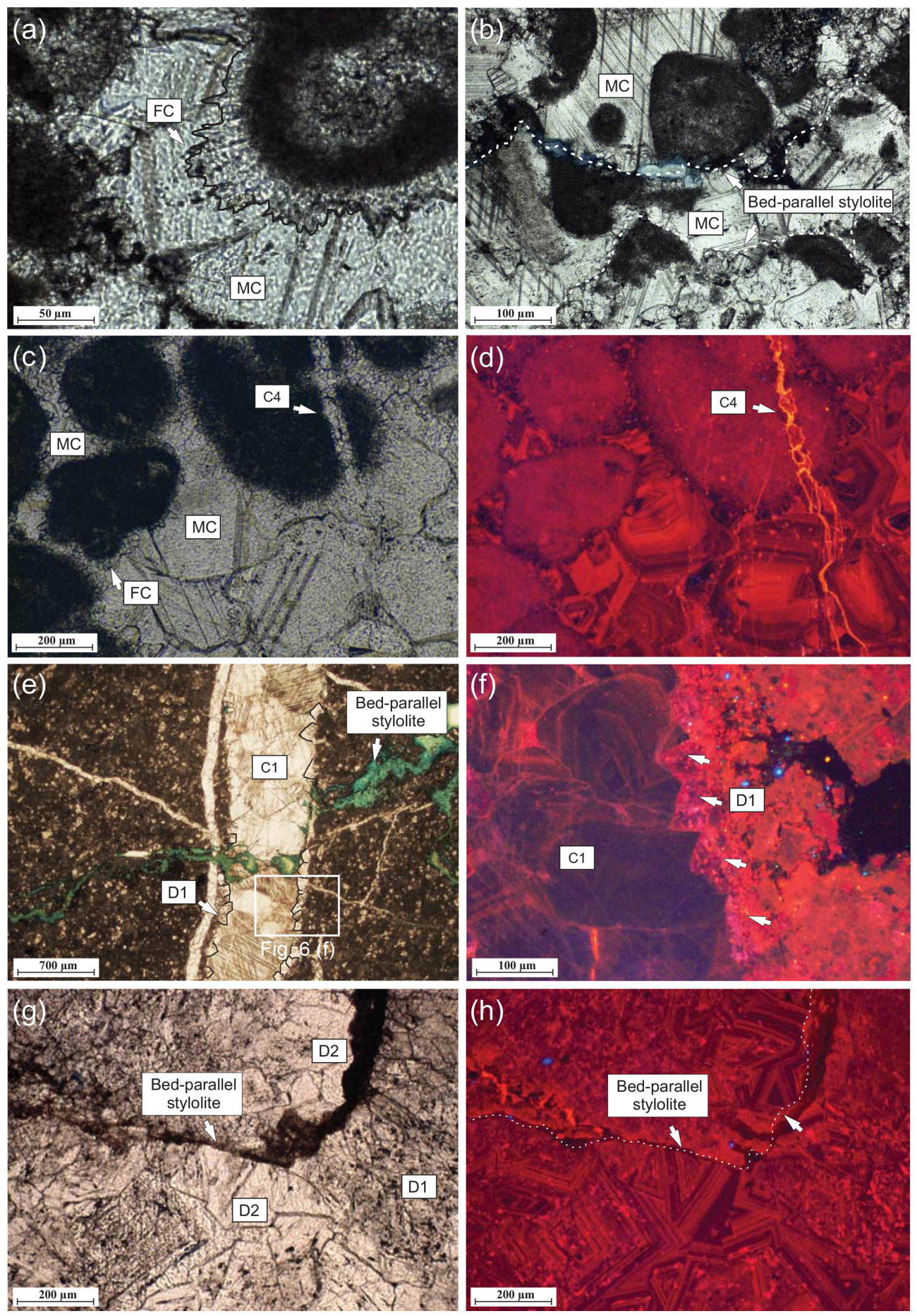

Figure 6. Undolomitized and dolomitized Calcare Massiccio Formation in field site d. (a) Transmitted light image showing a micritic peloid rimmed by fibrous cements (FC) which are overgrown by mosaic cements (MC). (b) Transmitted light image showing mosaic cements (MC) in a peloidal limestone overprinted by high-amplitude bed-parallel stylolites (dotted white line). Note the core of some of the peloids is partially cemented as well. (c, d) Transmitted light and corresponding cathodoluminescence image, respectively, of FC and MC cements. (e) Transmitted light photomicrograph showing D1 crystals (arrows) lining a fracture which is cemented by C1. The fracture is in turn affected by a bed-parallel stylolite. (f) Cathodoluminescence image showing D1 scattered in the host rock and riming the fracture. (g, h) Transmitted light and corresponding cathodoluminescence image, respectively, showing part of a bed-parallel stylolite (dotted white line) overprinting D1 and D2 crystals. 
rims fracture walls cemented by calcite (Fig. 6e and f). D1 postdates the micritic envelopes and early calcite cements, and predates high-amplitude bed-parallel stylolites (Fig. $6 \mathrm{~g}$ and $\mathrm{h})$. The crystals are fine-to-medium sized $(<350 \mu \mathrm{m})$ with planar-e and planar-s textures consisting of relatively turbid (rich in host rock solid inclusions) well-developed crystals. They show red luminescence when viewed under cathodoluminescence.

Dolomite 2 (D2) is a replacive dolomite (Fig. 7a and b), infrequently occluding existing pore spaces. Like D1, it also predates high-amplitude bed-parallel stylolites (Fig. $6 \mathrm{~g}$ and h). D2 generally exhibits a closely packed texture with no or little intercrystalline porosity. The crystals are mediumto-coarse sized $(\leq 500 \mu \mathrm{m})$ with planar-s to nonplanar textures. They include a turbid core followed by a transparent rim and trace quantities of saddle dolomite developing sweeping extinction. In some crystals, one additional turbid zone rich in host rock solid inclusions and fluid inclusions of mostly monophase is present. Cathodoluminescence observations enabled us to recognize the presence of D1 in their turbid cores. D2 crystals are characterized by zones of bright red-pink luminescence separated by purple luminescence zones (Fig. 7b).

Dolomite 3 (D3) is present as small localized bodies in the Calcare Massiccio (at the Castel Manfrino reference section), in the Corniola Formation (at the Osso Caprino road), and in the Calcare Massiccio and Bugarone formations (at the Corano Quarry) (Figs. 1b and 2a). In the Corano Quarry the dolomitized Bugarone and Calcare Massiccio formations are in the footwall of the Montagna dei Fiori Fault; juxtaposed to the undolomitized, intensely foliated Scaglia Formation in the hanging wall. The SEM and BSEM analyses performed on the samples from the immediate adjacent Scaglia Formation within the aforementioned fault damage zone do not indicate the presence of any dolomite in this formation. Within the Bugarone Formation in this fault damage zone, D3 locally cements the millimeter-sized angular breccias that are in turn affected by fault-parallel stylolites (Fig. 7c and d). D3 crystals are fine-to-medium sized $(<300 \mu \mathrm{m})$ exhibiting planar-e to nonplanar textures, with minor development of saddle morphologies of larger crystals $(>500 \mu \mathrm{m})$ with planar-c texture (Fig. 7e to h). The replacive crystals display a faint core, which compared to previous dolomite types has fewer solid inclusions. The saddle crystals are occasionally replacive. They display typical curved and slightly serrated crystal terminations with sweeping extinction. These saddle dolomites were only observed in the Castel Manfrino reference section. D3 generally exhibits a dark purple color with bright orange zones and subzones in core and/or rims when viewed under cathodoluminescence (Fig. 7e to h).

Dolomite 4 (D4) appears as a matrix replacive and dolomite cement surrounding porosity, and locally replacing D1 and D2 (Fig. 8a to f). D4 also occludes bed-parallel shear fractures and appears along the bed-parallel stylolites (Fig. 9a to d). In the Castel Manfrino reference section, some intercrystalline vuggy porosity is filled with fine dolomite rhombs including D4 with relics of D2 within their core (Fig. 8e and f). This porosity may be preserved or partiallyto-completely filled by calcite (C4). D4 crystals have a turbid, solid-inclusion-rich core and transparent rim. They are fine-to-medium sized $(<200-350 \mu \mathrm{m})$, presenting planar-s and infrequent nonplanar textures. D4 exhibits a distinct luminescence pattern including a purple zone and an irregular green subzone.

Dolomite 5 (D5) occurs as crystals cementing microveins that cross-cut precursor dolomite types including dolomitic breccia fragments. In cemented breccias, D5 is postdated by C3. D5 presents a planar-c texture and is characterized by a bright red luminescence (Fig. 9e and f).

\subsubsection{Late calcite cementation}

Four generations of calcite postdating dolomitization and distributed only within the fault damage zones have been identified (Figs. 10 and 11):

Calcite 1 (C1) occurs only in Calcare Massicio limestones and dolostones and is represented as centimeter-sized veins with thicknesses that do not exceed $1.5 \mathrm{~cm}$. It is not clear whether the fracture opening and calcite precipitation was simultaneous (as shown in Ukar and Laubach, 2016). These veins are strata-bound bed-perpendicular with irregular fracture walls, exhibiting white color in the outcrops. They are present within the syn-rift-related extensional fault damage zones, postdating the first dolomite type (D1) and abutted by high-amplitude bed-parallel stylolites. C1 usually shows blocky to elongated crystal morphologies and displays well-developed deformation twinning planes (Type II of Burkhard, 1993). This calcite exhibits concentric zonation and brown zones alternate with orange luminescence zones (Fig. 11a and b).

Calcite 2 (C2) exclusively occurs in the intensely deformed Scaglia Formation within the fault damage zones (Fig. 11b, c and d) and correspond to tension gashes associated with stylolites (sensu Nelson, 1981). The thicknesses of these veins do exceed $1 \mathrm{~cm}$. They are usually discontinuous and branch to several microveins (thickness $<1 \mathrm{~mm}$ ) when their tips are not intersected by stylolites. $\mathrm{C} 2$ veins are mostly recorded in foliated shear deformation zones with well-defined S-C fabrics, exhibiting blocky, elongated to fibrous shapes with strongly developed tightly spaced deformation twinning planes (Type II of Burkhard, 1993). C2 displays brown-to-orange luminescence with locally darker sector zones. The brown-to-orange luminescence characteristic of $\mathrm{C} 2$ is similar to those of encasing Scaglia host rocks (Fig. 11c and d).

Calcite 3 (C3) occurs as cement, filling the Montagna dei Fiori main fault plane and isolated veins within its damage zone. These veins are centimeter sized with thicknesses of less than $2 \mathrm{~cm}$. The breccias are generally clast supported but locally $\mathrm{C} 3$ cements the brecciated fault infillings containing 

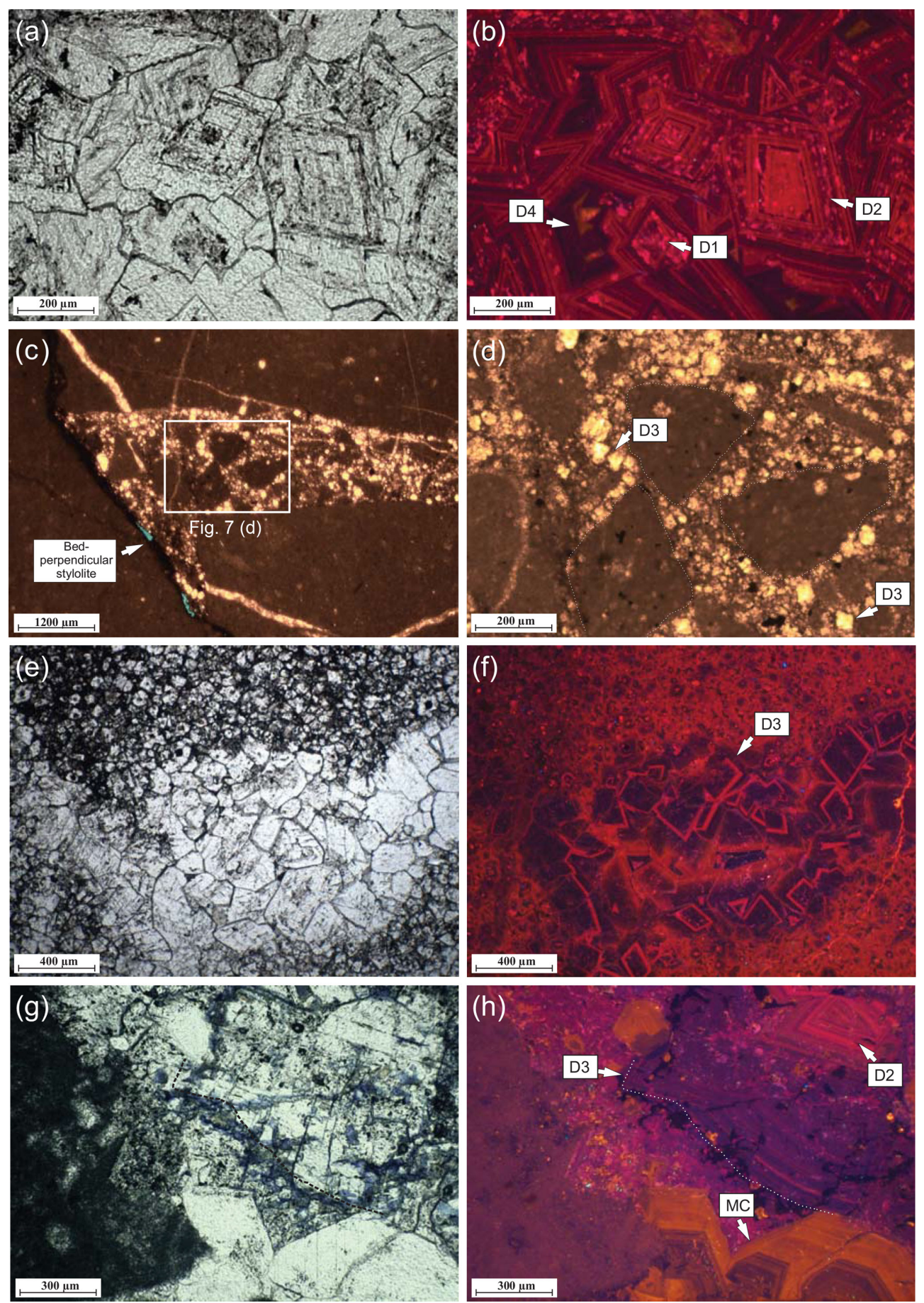

Figure 7. (a, b) Photomicrographs of transmitted light and corresponding cathodoluminescence image, respectively, showing the zoned rhombs of D2 with the remnants of D1 preserved in their cloudy core sampled from dolomitized Calcare Massiccio Formation in field site d. The pore space is occluded by D4. (c, d) D3 cementing angular breccia fragments of the Bugarone Formation in the damage zone of the Montagna dei Fiori Fault in the Corano Quarry site. Note the breccia is overprinted by a fault-parallel bed-perpendicular stylolite. (e, f) Photomicrographs of transmitted light and corresponding cathodoluminescence image, respectively, showing the euhedral to subhedral crystals of D3 entirely replacing the matrix and also present as cement developing a bright subzone and rim sampled from dolomitized Corniola Formation in Osso Caprino road. $(\mathbf{g}, \mathbf{h})$ D3 with a saddle crystal outline (SD) postdating calcite cements (MC) and a zoned D2 crystal. The saddle morphology is outlined by a dotted white line. 

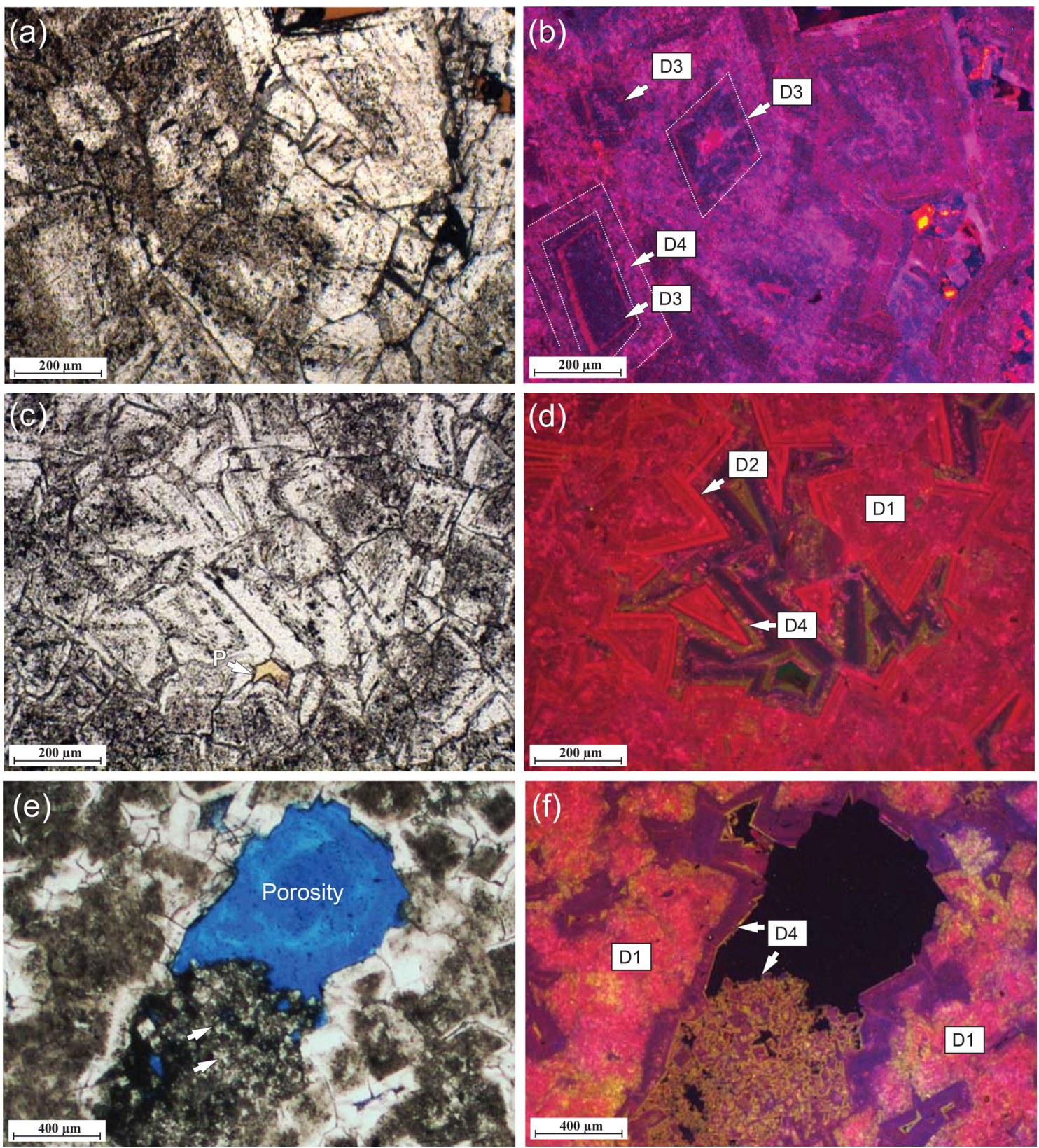

Figure 8. Photomicrographs from transmitted light and corresponding cathodoluminescence of dolomite types. (a, b) The cross-cutting relationship between D3 and D4 sampled from dolomitized Corniola Formation in Osso Caprino road is shown. Note the presence of D3 within the core of dolomite crystals overgrown by D4. (c, d) Successions of dolomite types sampled from dolomitized Calcare Massiccio Formation in field site f. Note the green CL color of D4 crystals. Typically, luminescent dolomites are known to show yellow or orange-to-red colors (Machel et al., 1991). Green luminescence in carbonates including dolomite have been attributed by a number of researchers to the incorporation of three valent rare-earth elements (REE) such as $\mathrm{Dy}^{3+}$ and $\mathrm{U}^{3+}$ as luminescence activators within their crystal lattice (Luczaj and Goldstein, 2000). Another possibility is the emplacement of $\mathrm{Mn}^{2+}$, with yellow luminescence, in $\mathrm{Ca}^{2+}$ sites with blue luminescence in the dolomite crystal lattice instead of preferential incorporation in the $\mathrm{Mg}^{2+}$ site (Sommer, 1972; Amieux, 1982; Walker et al., 1989; Habermann et al., 1999). Accordingly, non-stoichiometric Ca-rich poorly ordered dolomites may favor $\mathrm{Mn}^{+2}$ incorporation into their $\mathrm{Ca}^{2+}$ site. (e, f) Vuggy porosity rimmed by D4 (green CL). Note the porosity is filled with fine dolomite rhombs including traces of D2 in their core and D4 overgrowths. 

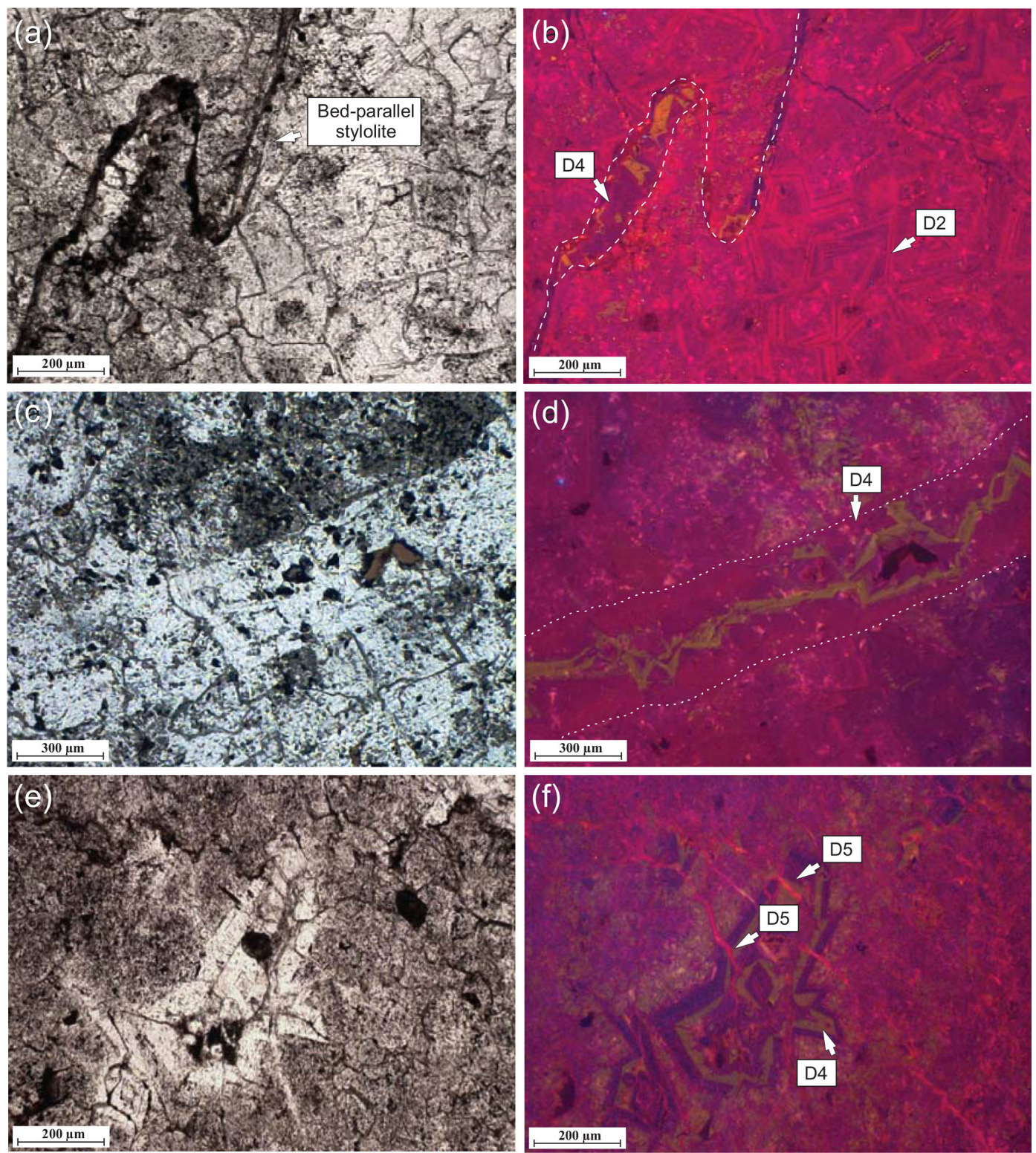

Figure 9. Photomicrographs showing transmitted light and corresponding cathodoluminescence images of D4 and D5 in relation to stylolites and fracturing. (a, b) D4, exploiting a bed-parallel stylolite that cross-cuts D1 and D2 sampled from dolomitized Calcare Massiccio Formation in field site d. (c, d) A subhorizontal fracture cemented by D4 sampled from dolomitized Corniola Formation in field site f. (e, f) D5 microveins (arrows) intersecting all the predating dolomite types in the footwall brecciated zone of the Montagna dei Fiori Fault, sampled from dolomitized Calcare Massiccio Formation in Castel Manfrino site.

angular fragments of host rock limestones, dolostones, and earlier calcites. In the brecciated zones, C3 always passively overgrows D5 in fractures and never cuts it. C3 exhibits a translucent white color in hand specimen. The crystals are blocky with no or weakly developed deformation twinning planes and are characterized by a dark-orange-to-brown luminescence with distinct darker sector zones (Fig. 11e and f).

Calcite vein $4(\mathrm{C} 4)$ exists as centimeter-sized isolated veins, pore filling, and breccia cements postdating all the preceding dolomites and calcites in the Montagna dei Fiori main fault plane. The breccia fragments are usually dolostones. C4 has a translucent white color in hand specimen with blocky crystal morphology and no evidence of subsequent deformation (e.g., deformation twinning planes), and is characterized by distinct concentric zonation (Fig. 11g and $\mathrm{h}$ ). 

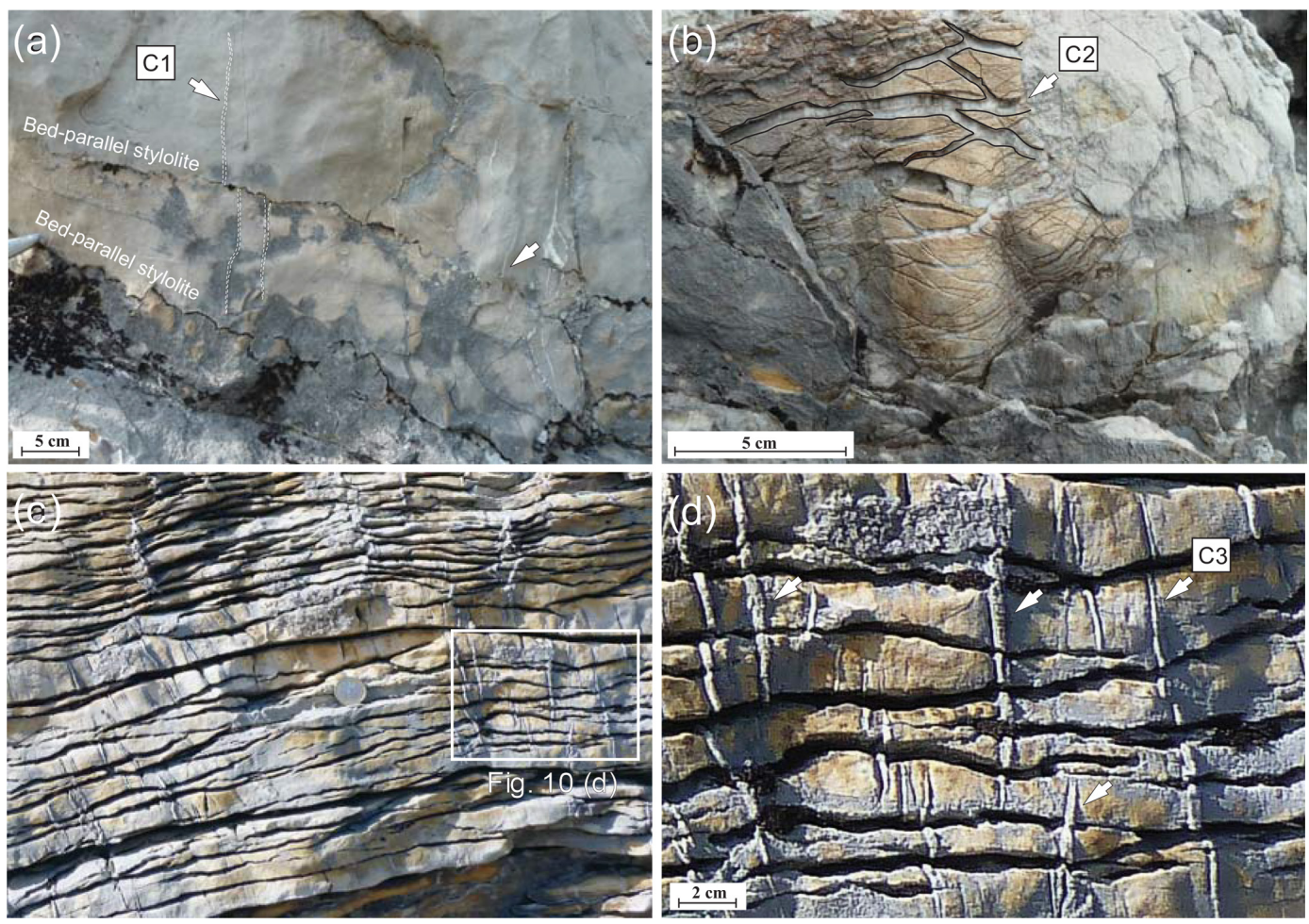

Figure 10. Field photographs showing the major calcite vein settings observed in Montagna dei Fiori. (a) Cross-sectional view of bed-normal calcite vein 1 (C1) abutting bed-parallel stylolites in folded beds of the Calcare Massiccio Formation. (b) Plan view of the calcite vein 2 (C2) intensely affecting the deformed Scaglia (Rossa) Formation. (c, d) Cross-sectional view of the Scaglia Formation intensely affected by pressure solution seams of tectonic origin crossed over by populations of bed-perpendicular calcite veins (C3) in en echelon extensional arrays.

Table 1. Stable carbon and oxygen isotopes, ${ }^{87} \mathrm{Sr} /{ }^{86} \mathrm{Sr}$ ratios, and fluid inclusion microthermometry data (not pressure corrected) of host rocks and diagenetic phases in the Montagna dei Fiori Anticline. Stable carbon and oxygen isotopes values are expressed in \%o V-PDB and salinity values in eq. wt $\% \mathrm{NaCl}$.

\begin{tabular}{|c|c|c|c|c|c|c|}
\hline & \multicolumn{2}{|c|}{ Stable isotopes } & \multirow{2}{*}{$\begin{array}{l}\text { Sr isotopes } \\
{ }^{87} \mathrm{Sr} /{ }^{86} \mathrm{Sr}\end{array}$} & \multicolumn{2}{|c|}{ Fluid inclusion microthermometry } & \multirow[b]{2}{*}{$n$} \\
\hline & $\delta^{13} \mathrm{C}$ & $\delta^{18} \mathrm{O}$ & & $\operatorname{Th}\left({ }^{\circ} \mathrm{C}\right)$ & Salinity & \\
\hline Calcare Massiccio Fm. & +2.4 to +3.1 & -1.6 to 0.0 & 0.70766 & - & - & \\
\hline Corniola Fm. & +2.0 to +2.5 & -3.1 to -1.4 & 0.70725 & - & - & \\
\hline Scaglia Fm. & +1.0 to +3.1 & -2.2 to -1.0 & $0.70784-0.70791$ & - & - & \\
\hline D1 & +2.5 & -1.9 & 0.70789 & $\leq 40-50$ & 3.5 to 11.3 & 27 \\
\hline CV1 & +1.6 to +2.1 & -4.7 to -2.7 & 0.70773 & - & - & - \\
\hline D2 & - & - & - & $\leq 40-50$ to 71 & 7.9 to 20.5 & 37 \\
\hline D3 & +2.0 to +2.6 & -2.8 to -1.9 & $0.70859-0.70964$ & 70 to 73 & 9.2 to 16.9 & 9 \\
\hline D4 & +2.4 to +2.5 & -3.0 to -2.5 & 0.70790 & 79 to 105 & 12.8 to 18.6 & 7 \\
\hline $\mathrm{CV} 2$ & +1.2 to +3.1 & -1.7 to -1.6 & $0.70779-0.70787$ & - & - & \\
\hline CV3 & +0.5 to +2.4 & -2.2 to 0.0 & - & $\leq 40-50$ & 4.5 to 9.7 & 9 \\
\hline CV4 & +3.8 to +4.9 & -9.4 to -9.1 & - & $\leq 40-50$ & 0.17 to 3.0 & 19 \\
\hline
\end{tabular}

\subsection{Geochemistry}

\subsubsection{Carbon and oxygen stable isotopes}

The carbon and oxygen stable isotopic data $\left(\delta^{13} \mathrm{C}\right.$ and $\left.\delta^{18} \mathrm{O}\right)$ of host rocks, dolomites, and calcites are given in Table 1 and shown in Fig. 12a and b. The marine stable isotopic compositions reported by Veizer et al. (1999) were used as marine reference values. Accordingly, Lower Jurassic marine limestones are characterized by $\delta^{13} \mathrm{C}$ values of $-0.5 \%$ o to $+4.5 \%$ and $\delta^{18} \mathrm{O}$ values of $-2.5 \%$ to $+1.0 \%$ V-PDB. The 

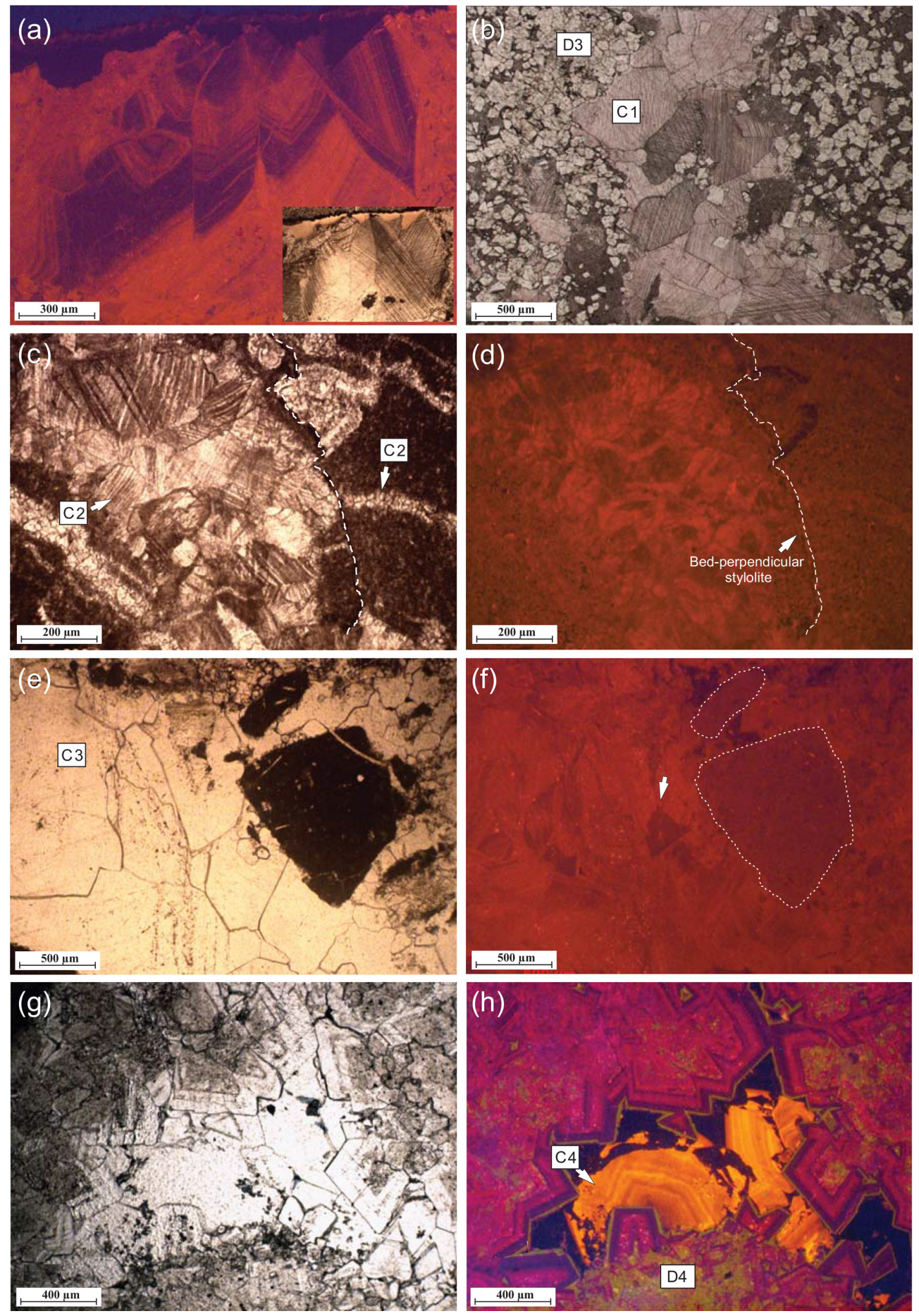

Figure 11. (a) Cathodoluminescence and transmitted light (inset) images showing blocky-to-elongated crystals of C1 with zoned CL pattern in the Corano Quarry site. (b) Transmitted light image showing intensely twinned C1 crystals overprinted by euhedral to subhedral crystals of D3 in the Corano Quarry site. Photomicrographs of transmitted light and corresponding cathodoluminescence image: (c, d) C2 in the Scaglia Formation abutted by a bed-perpendicular stylolite (indicated by white arrows and dashed line) in the Corano Quarry site. The crystals display blocky to fibrous morphologies, deformation twinning, and a similar orange luminescence pattern similar to the adjacent host rock. (e, f) C3 cementing the breccia fragments in the damage zone of the Montagna dei Fiori Fault. The crystals are blocky and show faint deformation twinning. They are brown-orange with distinct darker luminescence sector zones. (g, h) $\mathrm{C} 4$ presents as a cement within a polygonal pore space rimmed by dolomite, sampled from dolomitized Calcare Massiccio Formation in field site f. Note the blocky crystals, absence of deformation twinning, and distinct concentric luminescence zonation pattern. C4 is corroded and followed by a late telogenetic calcite. 
$\delta^{18} \mathrm{O}$ values of the marine dolomites are known to be $3 \% o_{-}$ $4 \%$ V-PDB more enriched than those of cogenetic marine limestones (Land, 1980; Major et al., 1992; Horita, 2014). In order to avoid data ambiguity due to physical mixing, this analysis was not separately performed on early calcite cements ( $\mathrm{FC}$ and $\mathrm{MC}$ ). The $\delta^{13} \mathrm{C}$ and $\delta^{18} \mathrm{O}$ values were measured on bulk samples of host rock limestones. Both $\delta^{13} \mathrm{C}$ and $\delta^{18} \mathrm{O}$ values of the host rocks are within the expected range of the Lower Jurassic marine limestones but the Corniola host rocks show slightly lower values comparing to those of Calcare Massiccio. In the Calcare Massiccio host rocks, the $\delta^{13} \mathrm{C}$ values plot between $+2.4 \%$ and $+3.1 \%$ and $\delta^{18} \mathrm{O}$ values are within the range of $-1.6 \%$ and $0.0 \% \mathrm{~V}$ PDB. The $\delta^{13} \mathrm{C}$ values in the Corniola host rocks are $+2.0 \%$ o and $+2.5 \%$ while the $\delta^{18} \mathrm{O}$ values are $-3.1 \%$ o to $-1.4 \%$ o V-PDB. The $\delta^{13} \mathrm{C}$ and $\delta^{18} \mathrm{O}$ values of the Scaglia host rocks range between $+1.0 \%$ and $+3.3 \%$ for $\delta^{13} \mathrm{C}$ and $-2.2 \%$ to $-1.0 \%$ V-PDB for $\delta^{18} \mathrm{O}$. The values obtained are characterized in the mean range of Upper Cretaceous to Paleogene marine limestones (Veizer et al., $1999 ;+1.0 \%$ o to $+4.5 \%$ o for $\delta^{13} \mathrm{C}$ and $-4.0 \%$ to $+2.0 \%$ o V-PDB for $\delta^{18} \mathrm{O}$ ).

The $\delta^{13} \mathrm{C}$ values of $\mathrm{C} 1$ are between $+1.6 \%$ and $+2.1 \%$, which plot within the range of reference values (Jurassic) but are slightly lower than the surrounding host rock values. The $\delta^{18} \mathrm{O}$ values are between $-4.7 \%$ and $-2.7 \%$ V-PDB, which are lower than those of reference and host rock values.

The $\delta^{13} \mathrm{C}$ values of all dolomite types $(+0.6 \%$ o to $+3.4 \%$ ) fall within the range of host rocks and Jurassic marine limestones (Veizer et al., 1999). The $\delta^{18} \mathrm{O}$ shows a wider range of values, overlapping but also lower than host rocks $(-4.5 \%$ o to $-0.9 \%$ V-PDB) and those expected for the Lower Jurassic marine dolomites. The majority of values plot between $-3.5 \%$ and $-1.5 \%$ V-PDB. The small size and overgrowth nature of certain dolomite types (e.g., D2 and D5) limit their proper isolation for geochemical analyses. Only one sample from $\mathrm{D} 1$ dolomite could be measured for $\delta^{13} \mathrm{C}$ and $\delta^{18} \mathrm{O}$ values, showing $+2.5 \%$ and $-1.9 \%$ V-PDB, respectively. The $\delta^{13} \mathrm{C}$ and $\delta^{18} \mathrm{O}$ values of $\mathrm{D} 3$ dolomite range from $+2.0 \%$ to $+2.6 \%$ and $-2.8 \%$ o to $-1.9 \%$ V-PDB, respectively, with values lower than those of the host rock.

D4 dolomite has $\delta^{13} \mathrm{C}$ values between $+2.4 \%$ and $+2.5 \%$, and $\delta^{18} \mathrm{O}$ values of $-3.0 \%$ to $-2.5 \%$ V-PDB. The $\delta^{13} \mathrm{C}$ and $\delta^{18} \mathrm{O}$ values of $\mathrm{C} 2$ are $+1.2 \%$ o to $+3.1 \%$ and $-1.7 \%$ o to $-1.7 \%$ V-PDB, respectively. The $\delta^{13} \mathrm{C}$ values of $\mathrm{C} 3$ are between $+0.5 \%$ and $+2.4 \%$, and the $\delta^{18} \mathrm{O}$ values cover a range of $-2.2 \%$ to $0.0 \%$ V-PDB. The $\delta^{13} \mathrm{C}$ and $\delta^{18} \mathrm{O}$ values of $\mathrm{C} 4$ are $+3.8 \%$ o to $+4.9 \%$ and $-9.4 \%$ o to $-9.1 \%$ V-PDB, respectively. The $\delta^{13} \mathrm{C}$ values are slightly higher but the $\delta^{18} \mathrm{O}$ values are considerably lower compared to preceding calcite generations and the measured values from host rocks.
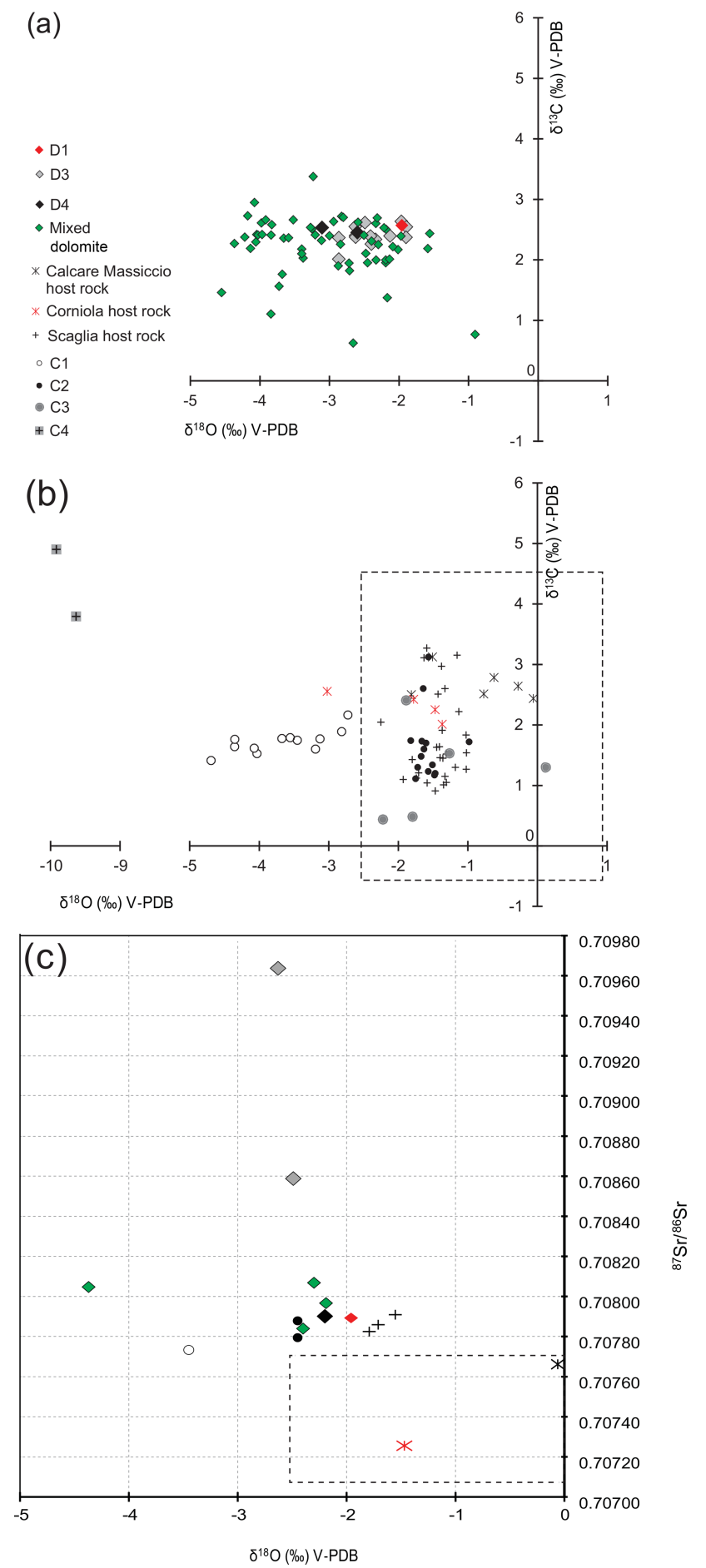

Figure 12. Overview of the $\delta^{13} \mathrm{C}$ and $\delta^{18} \mathrm{O}$ values of dolomites (a) host rocks from Montagna dei Fiori as well as calcite veins (b). The stable isotope value of Lower Jurassic marine limestones based on Veizer et al. (1999) is indicated by a dashed rectangle in subset B. The $\delta^{18} \mathrm{O}$ values of the marine dolomites are considered to be $3 \%$ 4\%o V-PDB higher than those of marine limestones (Land, 1980; Major et al., 1992; Horita, 2014). (c) Cross plot of ${ }^{87} \mathrm{Sr} /{ }^{86} \mathrm{Sr}$ ratios and corresponding $\delta^{18} \mathrm{O}$ values of host rocks, dolomites, and calcite veins compared with Lower Jurassic marine carbonates ${ }^{87} \mathrm{Sr} /{ }^{86} \mathrm{Sr}$ (dashed rectangle) framework reported by McArthur et al. (2012). 


\subsection{2 ${ }^{87} \mathrm{Sr} /{ }^{86} \mathrm{Sr}$ ratios}

Samples from host rocks (i.e., Calcare Massiccio and Corniola formations), dolomites (D1, D3, and D4), and the Scaglia Formation in juxtaposition with the dolostones were analyzed for their ${ }^{87} \mathrm{Sr} /{ }^{86} \mathrm{Sr}$ isotopic ratios. The obtained ratios versus $\delta^{18} \mathrm{O}$ values of the analyzed samples are shown in Fig. 12c. The ${ }^{87} \mathrm{Sr} /{ }^{86} \mathrm{Sr}$ ratios obtained from the Calcare Massiccio and Corniola limestones are 0.70766 and 0.70725 $(n=2)$, respectively, which is in agreement with the values of the Lower Jurassic marine carbonates (0.70704-0.70768) reported by McArthur et al. (2012). CV1 shows a value equal to 0.70773 .

All the dolomite types display higher ${ }^{87} \mathrm{Sr} /{ }^{86} \mathrm{Sr}$ ratios when compared to the host rocks and reference values of the Lower Jurassic marine carbonates. D1 (replacive) and D4 cements show a similar narrow range with values between 0.70784 and 0.70790 . The two D3 samples (replacive and cement) display higher ${ }^{87} \mathrm{Sr} /{ }^{86} \mathrm{Sr}$ ratios $(0.70858$ and 0.70963 , respectively). The ${ }^{87} \mathrm{Sr} /{ }^{86} \mathrm{Sr}$ ratios obtained for dolomites do not show covariation with corresponding $\delta^{18} \mathrm{O}$ values. The radiogenic Sr analysis was not performed on D2 and D5 since the physical mixing with other dolomite types could not be avoided.

The ${ }^{87} \mathrm{Sr} /{ }^{86} \mathrm{Sr}$ ratios of the three marly limestone samples of Scaglia Formation are 0.70784 to 0.70790 . The C2 veins in Scaglia Formation show similar ratios of 0.70779 and 0.70787 . These values fit within the limits of values assigned by McArthur et al. (2012) for the Cenomanian to Bartonian (Scaglia age) marine carbonates $(0.70730-0.70790)$.

\subsection{Fluid inclusion microthermometry}

The overview of microthermometry measurements is given in Table 1 and Fig. 13a to c. All the measured fluid inclusions are primary and occur in growth zones. Based on optical and fluorescence microscopy analysis of wafers, all the inclusions are aqueous monophase (liquid) or have two phases (liquid and vapor) with relatively consistent $\mathrm{L}: \mathrm{V}$ ratios of $10 \%-15 \%$ within a single FIA (fluid inclusion assemblage). Special care was taken to avoid the samples that occasionally displayed scattered mottled luminescence that may indicate recrystallization.

D1 contains dominantly monophase aqueous inclusions with sizes greater than $5 \mu \mathrm{m}$. All the inclusions froze at -65 to $-49^{\circ} \mathrm{C}$. The first melting $(\mathrm{Te})$ was detected between -22 and $-19.3^{\circ} \mathrm{C}$. The final ice melting $(\mathrm{Tm})$ appeared at temperatures between -7.7 and $-2{ }^{\circ} \mathrm{C}$. Applying the equation of Bodnar (1993), the obtained final melting temperatures correspond to salinity ranges of 3.5 to 11.3 eq. wt $\% \mathrm{NaCl}$.

$\mathrm{D} 2$ is characterized by the presence of monophase and infrequent two-phase inclusions generally within their growth zones. The homogenization temperature of two-phase inclusions varies between 58 and $71^{\circ} \mathrm{C}$. Upon cooling, a complete freezing of the fluid phase is reached at -56 to $-40^{\circ} \mathrm{C}$. The first ice melting temperature was distinguished at $-22^{\circ} \mathrm{C}$. The final ice melting temperatures fall within -17.5 and $-5^{\circ} \mathrm{C}$, corresponding to salinities between 7.9 and 20.5 eq. wt $\% \mathrm{NaCl}$.

D3 is commonly inclusion poor. The measurable inclusions were detected and examined only in saddle dolomite crystals. These crystals contain only two-phase aqueous inclusions. Their homogenization temperatures are within the narrow range of 70 to $73^{\circ} \mathrm{C}$. The complete freezing and first ice melting temperatures could not be distinguished but the final ice melting temperature occurred at temperatures between -13 and $-6^{\circ} \mathrm{C}$ equal to salinity ranges of 9.2 to 16.9 eq. wt $\% \mathrm{NaCl}$. The first melting temperatures of fluid inclusions in D1, D2, and D3 were about $-21^{\circ} \mathrm{C}$, suggesting a $\mathrm{H}_{2} \mathrm{O}-\mathrm{NaCl}$ fluid system.

D4 contains only two-phase aqueous inclusions. The homogenization temperatures in D4 vary between 79 and $105^{\circ} \mathrm{C}$. Complete freezing of inclusions occurred at temperatures between -86 and $-54^{\circ} \mathrm{C}$. The first ice melting was detected from -35 to $-40^{\circ} \mathrm{C}$ indicating the possible presence of divalent cations such as $\mathrm{Ca}^{2+}$ and/or $\mathrm{Mg}^{2+}$ in the fluids (Shepherd et al., 1985; Goldstein and Reynolds, 1994). The final ice melting temperatures fall within a range of -15 and $-9^{\circ} \mathrm{C}$ corresponding to salinities of 12.8 to 18.6 eq. wt $\% \mathrm{NaCl}$. A couple of inclusions show homogenization temperatures exceeding $120^{\circ} \mathrm{C}$ with salinities higher than 20 eq. wt $\% \mathrm{NaCl}$.

No measurable fluid inclusion could be identified in $\mathrm{C} 1$ and $\mathrm{C} 2$ due to intense deformation twinning. $\mathrm{C} 3$ and $\mathrm{C} 4$ contain only primary monophase aqueous inclusions, indicating an entrapment temperature of below about $40-50{ }^{\circ} \mathrm{C}$ (Goldstein and Reynolds, 1994). A complete freezing of the inclusions in $\mathrm{C} 3$ occurred at temperatures between -40 and $-52.5^{\circ} \mathrm{C}$. The first melting temperature was detected at about -21 to $-22^{\circ} \mathrm{C}$, suggesting a $\mathrm{H}_{2} \mathrm{O}-\mathrm{NaCl}$ composition. The final melting temperatures range between -6.4 and $-2.7^{\circ} \mathrm{C}$, corresponding to salinities between 9.7 and 4.5 eq. wt $\% \mathrm{NaCl}$. The majority of the values cluster between 7.8 and 5 eq. wt $\% \mathrm{NaCl}$.

The complete freezing temperatures of the inclusions in $\mathrm{C} 4$ fall within -46 and $-35.5^{\circ} \mathrm{C}$. The first melting temperature could not be determined with confidence but the final melting temperatures were reached at about -0.1 to $-1.8^{\circ} \mathrm{C}$, corresponding to salinities of 0.17 to 3.0 eq. wt $\% \mathrm{NaCl}$.

\section{Discussion}

\subsection{Stable and radiogenic isotopic composition of the parental fluids}

The $\delta^{13} \mathrm{C}$ values of all dolomite types mimic the range of host rock and Jurassic marine limestones and, consequently, they can be interpreted as largely rock buffered. Their $\delta^{18} \mathrm{O}$ values are partly similar to those of their respective host 

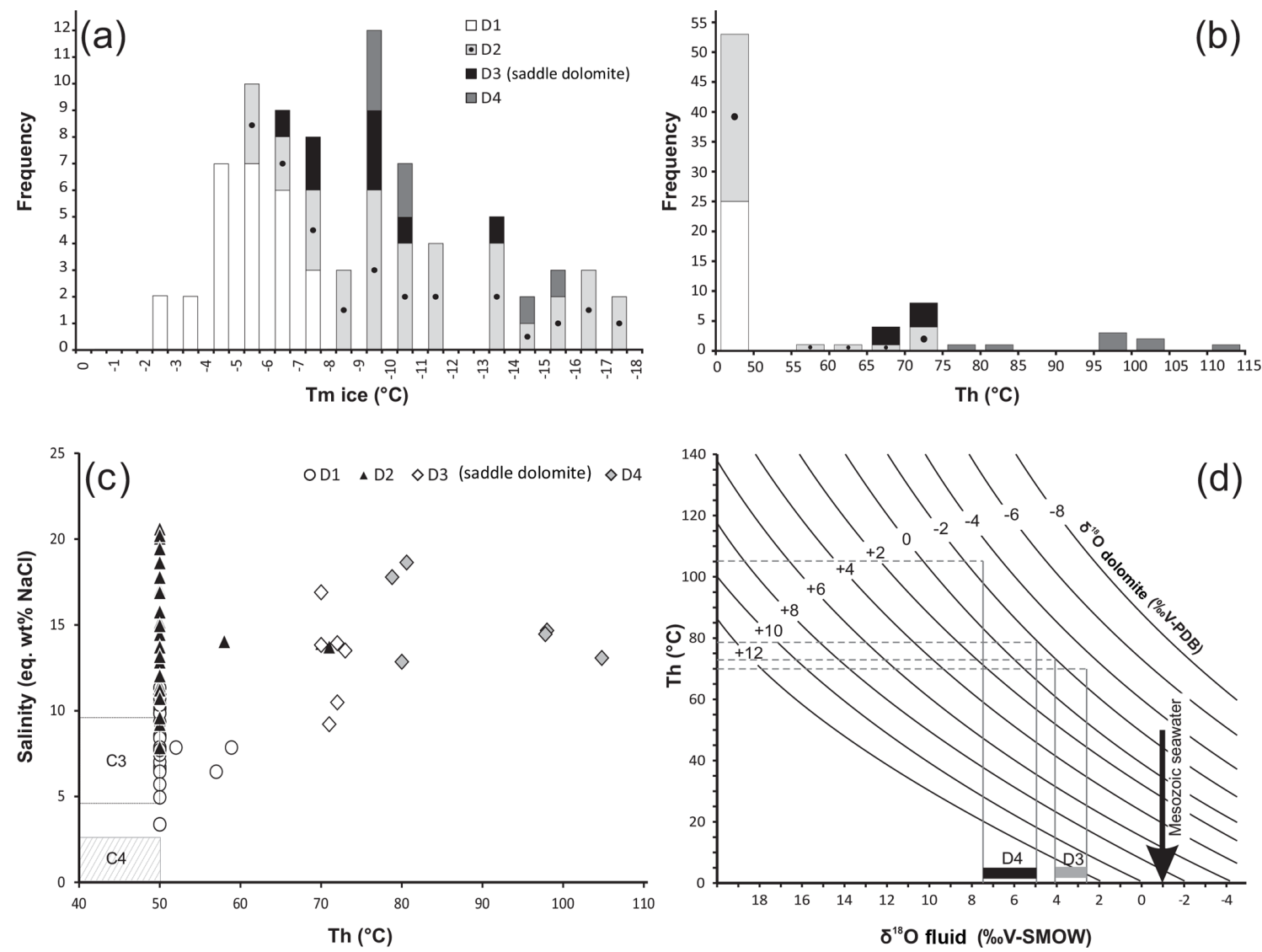

Figure 13. Overview of microthermometry analysis of primary inclusions in Montagna dei Fiori. (a) Frequency distribution of the Tmice $\left({ }^{\circ} \mathrm{C}\right.$ ) in dolomite types. (b) Frequency distribution of the Th $\left({ }^{\circ} \mathrm{C}\right)$ in dolomite types. (c) Salinity (eq. wt $\% \mathrm{NaCl}$ ) versus Th $\left({ }^{\circ} \mathrm{C}\right)$ of dolomite and calcite phases. (d) Isotopic fractionation diagram from Land (1983) used to determine the isotopic composition (\%o V-SMOW, Vienna Standard Mean Ocean Water) of parental fluids in equilibrium with dolomites in Montagna dei Fiori.

rocks as well as Jurassic marine reference values but more depleted when compared to the presumable Jurassic marine dolomites. The relatively depleted $\delta^{18} \mathrm{O}$ dolomite values could indicate the contribution of heated fluids in dolomitization process, although they could also relate to recrystallization of a precursor dolomite by fluids at higher temperature or ${ }^{18}$ O-depleted dolomite (Land, 1980, 1985). The absence of distinctive textural evidence in the analyzed samples such as enlarged crystal size and/or systematic mottled cathodoluminescence pattern, and their covariation with $\delta^{18} \mathrm{O}$ values, do not confirm recrystallization (Mazzullo, 1992, and references therein).

The oxygen isotope fractionation relation between water and dolomite (Land, 1983) was used to determine the most plausible parental fluids. In order to avoid erroneous results due to rock-buffered $\delta^{18} \mathrm{O}$ values, only the $\delta^{18} \mathrm{O}$ values of dolomite cements, especially from the bed-parallel veins containing D4 were used. These values may provide the closest approximation to the $\delta^{18} \mathrm{O}$ signature of the parental fluids (Barker and Cox, 2011). Accordingly, a $\delta^{18} \mathrm{O}$ value of $\approx+2.5 \%$ o to $+4 \%$ \%-SMOW (Vienna Standard Mean
Ocean Water) was calculated for D3, while this values increase to $\approx+5 \%$ o to $+7.5 \%$ V-SMOW for D4 (Fig. 13d). The higher $\delta^{18} \mathrm{O}$ composition of the dolomitizing fluids relative to the Mesozoic seawater, which is estimated at $-1.2 \%$ o to $-1 \%$ V-SMOW (Shackleton and Kennett, 1975; Marshall, 1992; Saelen et al., 1996), is compatible with fluids derived from or that had interacted with siliciclastic rocks, crystalline basement (Taylor, 1997) and/or evaporite-derived brines.

The ${ }^{87} \mathrm{Sr} /{ }^{86} \mathrm{Sr}$ ratios obtained for all dolomite types are higher than the Lower Jurassic marine carbonate values (0.70704-0.70768; McArthur et al., 2012). Since marine carbonates have very low rubidium $(\mathrm{Rb})$ concentrations they produce negligible in situ radiogenic ${ }^{87} \mathrm{Sr}$ after their deposition (Stueber et al., 1972; Burke et al., 1982). Therefore, the higher ${ }^{87} \mathrm{Sr} /{ }^{86} \mathrm{Sr}$ ratios can be explained by the contribution of fluids originated or interacted with potassium rich siliciclastic rocks ( $\mathrm{K}$ feldspars), crystalline basement, and/or stratigraphic levels with higher ${ }^{87} \mathrm{Sr} /{ }^{86} \mathrm{Sr}$ ratios (Emery and Robinson, 1993; Banner, 2004). Taking into account that the Upper Triassic Burano Formation underlying the stud- 
ied intervals as the basal detachment has ${ }^{87} \mathrm{Sr} /{ }^{86} \mathrm{Sr}$ ratios between 0.70774 and 0.70794 (Boschetti et al., 2005), the ${ }^{87} \mathrm{Sr} /{ }^{86} \mathrm{Sr}$ ratios (D1 and D4) can partially be explained by their contribution. However, this contribution cannot justify much higher ${ }^{87} \mathrm{Sr} /{ }^{86} \mathrm{Sr}$ ratios recorded in D3, being higher than values reported for Phanerozoic seawater (McArthur et al., 2012), and the values obtained for the adjacent basinal deposits (i.e., Corniola and Scaglia formations). Therefore, parental fluids most likely originated from or had interacted with the siliciclastic rocks underlying the Burano Formation (Verrucano Formation), if present, and/or with the crystalline basement with common elevated ${ }^{87} \mathrm{Sr} /{ }^{86} \mathrm{Sr}$ ratios (0.71500-0.72650; Del Moro et al., 1982). The significantly higher ${ }^{87} \mathrm{Sr} /{ }^{86} \mathrm{Sr}$ ratios in D3 in comparison with other studied dolomites indicates a higher influence of ${ }^{87} \mathrm{Sr} /{ }^{86} \mathrm{Sr}$-rich fluids either due to major changes in the permeability architecture of faults or availability of such fluids. The lack of any ferroan diagenetic phase minimizes the interaction of fluids produced by clay transformation or dewatering (i.e., smectite to illite transformation; Boles and Franks, 1979).

$\mathrm{C} 1$ is characterized by $\delta^{13} \mathrm{C}$ and $\delta^{18} \mathrm{O}$ values lower than the host limestones (i.e., Calcare Massiccio), while its ${ }^{87} \mathrm{Sr} /{ }^{86} \mathrm{Sr}$ ratio is similar to them. The salinity and composition of the parental fluids cannot be inferred here since no measurable fluid inclusions were found within this cement. The ${ }^{87} \mathrm{Sr} /{ }^{86} \mathrm{Sr}$ ratio being within the range of the corresponding host rocks and the reference values, points to a rock-buffered system for ${ }^{87} \mathrm{Sr} /{ }^{86} \mathrm{Sr}$.

The $\delta^{13} \mathrm{C}$ and $\delta^{18} \mathrm{O}$ values obtained for $\mathrm{C} 2$, as well as ${ }^{87} \mathrm{Sr} /{ }^{86} \mathrm{Sr}$ ratios, fall within the range of the Scaglia host rocks, thus reflecting their rock-buffered nature. This interpretation is further supported by the similar luminescence characteristics of $\mathrm{C} 2$ with that of encasing Scaglia host rocks. The fluids from which $\mathrm{C} 2$ calcite precipitated, as expected for tension gashes, were most likely derived from carbonate dissolution during pressure solution and stylolitization of host rock, pointing to a closed fluid system in contrast with the subsequent vein generations.

C3 is characterized by $\delta^{13} \mathrm{C}$ values within the Jurassic marine values but are generally lower than the host rocks, while their $\delta^{18} \mathrm{O}$ values partially overlap both the hosting limestones and dolostones. Microthermometry of fluid inclusions revealed only monophase aqueous inclusions and thus precipitation at relatively low temperature $\left(\leq 40-50{ }^{\circ} \mathrm{C}\right)$ with moderate salinity (4.5-9.7 eq. wt $\% \mathrm{NaCl})$. Such levels of salinity can be assigned to evaporated seawater, residual brines or fluids derived from evaporite dissolution, and thus makes it difficult here to interpret their exact origin with the available data.

$\mathrm{C} 4$ is the latest calcite phase, and records the $\delta^{13} \mathrm{C}$ and $\delta^{18} \mathrm{O}$ values, respectively enriched and significantly depleted when compared to their hosting rocks and preceding diagenetic products. Generally, the enrichment of ${ }^{13} \mathrm{C}$ could suggest $\mathrm{CO}_{2}$ outgassing due to evaporation or pressure changes (Friedman, 1970; Hendry et al., 2015) or bacterial fermenta- tion (methanogenesis) of organic matter (Hudson, 1977) in low-temperature diagenetic environments. The homogenization temperature of $\mathrm{C} 4$, being below about $40-50^{\circ} \mathrm{C}$, could support any of these processes. Their low $\delta^{18} \mathrm{O}$ values and fluid inclusions with salinities similar to, but also significantly lower than, seawater reflect the contribution of meteoric fluids during precipitation of this calcite.

\subsection{Origin of the dolomitizing fluids}

The contribution of brines that derived from highly evaporated seawater or evaporites is suggested by the elevated salinity values obtained from microthermometry of the fluid inclusions ( 3.5 to 20.5 eq. wt $\% \mathrm{NaCl}$ ). Accordingly, two sources that could potentially provide such fluids can be proposed: (1) fluids related to the Late Messinian evaporites, associated with the overlying Upper Miocene Laga Formation, and their possible downward percolation through fault zones by density driven flow and/or seismic pumping mechanisms (Sibson, 1981; McCaig, 1988, 1990); or their tectonic involvement into the Apenninic thrust wedge during its propagation (underthrusting; Lobato et al., 1983); and (2) fluids related to the underlying detachment horizon of the Burano evaporites (Upper Triassic) and their upward flow through fault zones during development of the Montagna dei Fiori Anticline. The first scenario is valid if the dolomitization would have occurred only from the Upper Miocene time onwards. Moreover, several researchers (e.g., Vai and Ricci Lucchi, 1977; Bassetti et al., 1998; Roveri et al., 2001) have shown that the occurrence of primary shallow-water evaporites, which were dominantly gypsum, was limited only to the western and central parts of the northern Apennines consisting of thrust-top marginal basins (Roveri et al., 2001). Hence, the evaporitic horizons existing within the Laga Formation corresponds to resedimentation (gypsum debris) of those previously precipitated in the marginal basins. This interpretation makes the Messinian evaporites an unlikely source of Mg-rich brines. Taking into account that the maximum burial-related temperature of the Calcare Massiccio Formation did not exceed $80^{\circ} \mathrm{C}$ in the Montagna dei Fiori region (Ronchi et al., 2003), it is unlikely that the downward percolation of relatively low-temperature brines derived from the Messinian evaporites, located at higher stratigraphic levels, could reach or exceed the high temperatures recorded in fluid inclusions of the studied dolomites (D4; up to $105^{\circ} \mathrm{C}$ ), given that the homogenization temperatures reflect the minimum entrapment temperatures (Goldstein and Reynolds, 1994). Deep circulation of these brines, if they existed, can also be excluded by the fact that their limited involvement in the thrust wedge was confined merely to the offshore side of the Montagna dei Fiori region (Artoni, 2013).

Accordingly, the Upper Triassic Burano Formation - the basal detachment - appears as the most plausible source for the high-salinity brines recorded in fluid inclusions, and likewise the Mg-rich fluids could have originated from postevap- 
orite brines associated with them (Carpenter, 1978; McCaffrey et al., 1987). The fluctuations in salinity may argue for a diverse range of fault connectivity, different degrees of rockwater interaction, and contribution of pore waters of lower salinity (e.g., marine or meteoric).

\subsection{Timing and structural controls on the evolution of parental fluids}

A generalized paragenesis and the relative chronology of dolomitization in relation to the structural evolution of the Montagna dei Fiori Anticline are illustrated in Figs. 14 and 15. The structural episodes are based on the evolutionary stages of the Montagna dei Fiori Anticline suggested by Storti et al. (2018). The paragenesis is constructed on the basis of direct evidence recorded during observations at outcrop scale and microscopic observations (e.g., cross-cutting relationships between diagenetic phases, stylolites, fractures, and other structural kinematics), and indirect evidence (e.g., regional geodynamics and burial history).

The occurrence of micritic envelopes and fibrous calcite cements (FC), in grain-supported stratigraphic levels of the Calcare Massiccio Formation, is interpreted to be of eogenetic origin (i.e., marine phreatic diagenesis; Moore, 1989), reflecting an early diagenesis shortly after deposition. The well-developed brown-and-orange concentric cathodoluminescence pattern of the succeeding mosaic calcite cement (MC) suggests a progressive shift to more reducing conditions during precipitation in a phreatic diagenetic environment (as shown in Li et al., 2017). High-amplitude bed-parallel stylolites postdate both cements, which confirm their precipitation before significant burial. The observations made here are in agreement with earlier work by Giacometti and Ronchi (2000), interpreting that the Calcare Massiccio Formation was cemented during the early diagenetic stages.

D1, C1, and D2 are cut by well-developed high-amplitude bed-parallel stylolites. The presence of D1 and C1 in bedperpendicular veins typically cut by these stylolites (see Fig. 6e to h) support the interpretation that the first dolomitization event (D1 and D2) took place before significant burial and stylolite development. The latter and bed-perpendicular veins are dynamically compatible within the same stress field, which is characterized by a vertical load-related maximum principal axis of the stress ellipsoid (Fig. 15a). The dominantly monophase fluid inclusions within D1 and D2 are in agreement with precipitation temperatures below about $40-50{ }^{\circ} \mathrm{C}$, suggesting a relatively shallow to intermediate burial environment and hence supporting a pre-Apenninic orogeny age of precipitation from a mix of formational and extra-formational fluids with elevated ${ }^{87} \mathrm{Sr} /{ }^{86} \mathrm{Sr}$ ratios. The distribution of D1 and D2 localized near the rifting-related $\sim \mathrm{N}-\mathrm{S}$ - and E-W-striking extensional faults and even their displacement along them (Fig. 2a; e.g., site 1) point to the possible contribution of these faults in occurrence of D1 and D2. These faults dominantly affect the Jurassic rocks older than the Maiolica Formation which is attributed to post-rift deposits, therefore suggesting a pre-Maiolica age for these dolomite types. Although an absolute age cannot be provided, based on the evidence discussed above, the circulation of Mg-rich fluids during this dolomitization event was most likely controlled by rifting-related Jurassic extensional fault zones cutting through the crystalline basement. Precipitation of D1 and D2 at the lower part of Corniola Formation, which is known as the syn-rift deposit, discards a pre-rift origin for these dolomites. The displacement of dolomites along the aforementioned faults is possibly related to their prolonged activation during the Early Jurassic to Late Jurassic. In addition to the role of these faults in channelizing the fluids, their mobilization must have been intensified by some deriving mechanisms. A thermal convection system derived from high hit flux during rifting was interpreted by Hollis et al. (2017) to be responsible for circulation of seawater in a syn-rift dolomitization case in the Hammam Faraun fault block (Suez Rift, Egypt). In such a scenario, the salinity of the fluids and their ${ }^{87} \mathrm{Sr} /{ }^{86} \mathrm{Sr}$ ratios are expected to be more or less within the range of seawater. Furthermore, this scenario seems unlikely in the studied area given the lack of a deep aquifer to accommodate the fault tips and promote the lateral fluid flux from basin to the rift shoulders and vice versa. Taking into account that D1 and D2 are the volumetrically more relevant dolomites within the studied intervals, and assuming the likely role of syn-rift extensional faults (Early Jurassic to Late Jurassic) in their precipitation, a dominantly synrift dolomitization process is proposed for the dolostones in the Montagna dei Fiori Anticline. Although the CL zonation pattern observed in D2 may indicate changes in flow condition or fluid composition, the lack of physical disruptions such as multiple fracturing suggests external regional controls rather than slip along the same faults (Eichhubl and Boles, 2000). The absence of pervasive syn-dolomitization fracturing and brecciation as well as zebra fabrics in these dolomites perhaps indicate a relatively calm tectonic period during dolomite development (e.g., Hollis et al., 2017).

D3 and D4 both record elevated ${ }^{87} \mathrm{Sr} /{ }^{86} \mathrm{Sr}$ ratios which account for their fault-controlled origin. However, their occurrence at the top of the Calcare Massiccio and overlaying Bugarone Formation (Corano Quarry site), which is $<1 \mathrm{~m}$ thick in the Montagna dei Fiori region and is marked as the final rift deposit (Cardello and Doglioni, 2015), discards a syn-rift origin for these dolomites. Moreover, D3 and D4 postdate the development of high-amplitude bed-parallel stylolites. The formation of stylolites requires an approximate overburden of 600 to $1500 \mathrm{~m}$ (Lind et al., 1993; Machel, 1999; Mountjoy et al., 1999; Schulz et al., 2016), corresponding to a late to post-Maiolica deposition time (Early Cretaceous time onwards). The presence of D3 and D4 dolomites in bed-parallel fractures and as shear veins (D4) (Fig. 9a and b) suggests their association with contractional deformations, i.e., the most likely tectonic regime for explaining bed-perpendicular dilation. Therefore, the volumetrically mi- 


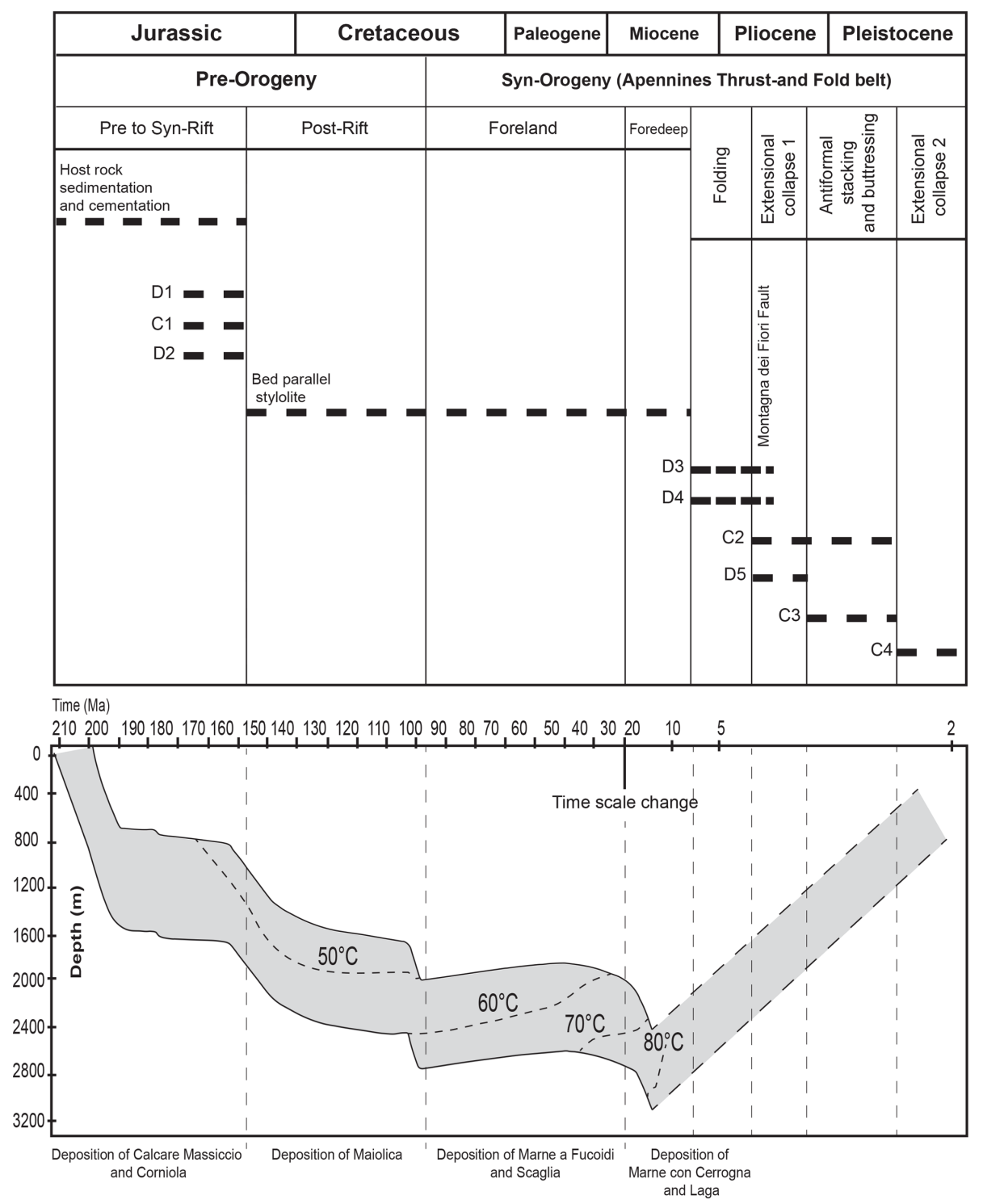

Figure 14. Generalized paragenesis of diagenetic phases in relation to deformational stages and burial history of the Calcare Massiccio Formation in the Montagna dei Fiori Anticline. The deformational stages are from Storti et al. (2018) and the burial curve is based on Ronchi et al. (2003). The burial curve was made based on paleodepth, paleotemperatures, sedimentation rate, and paleoheat flow.

nor second stage of dolomite precipitation may possibly be related to the Late Miocene to post-Miocene compressional tectonics recorded in this region (e.g., Mazzoli et al., 2002; Artoni, 2013; Storti et al., 2018).

Dolostones containing D3 and D4 appear commonly as clast-supported breccias along fault zones pertaining to the Montagna dei Fiori Fault, then overprinted by fault-parallel stylolites (Figs. 3 and 7). Accordingly, the occurrence of these dolomites was probably synchronous with the incipient stages of fault development, predating fault buttressing (Storti et al., 2018). Homogenization temperatures recorded in D4 (up to $105^{\circ} \mathrm{C}$ ), much higher than the maximum temperatures recorded in the host rocks (below about $80^{\circ} \mathrm{C}$;
Ronchi et al., 2003), suggest hydrothermal fluid circulation. The development of the Montagna dei Fiori Anticline at the toe of the Late Miocene Central Apennines thrust wedge could have favored the forelandward migration of hydrothermal fluids expelled from the more internal regions of the belt, similarly to what has been proposed for the Rocky Mountains foreland (i.e., squeegee flow model; Machel and Cavell, 1999). Such a migration may have possibly favored the precipitation of D4 in bed-parallel veins, generally considered evidence for syn-compressional fluid overpressure (Sibson, 2001; Hiemstra and Goldstein, 2015). At this stage, in addition to dilation of the pre-existing $\sim \mathrm{N}-\mathrm{S}$ - and $\mathrm{E}-\mathrm{W}$-striking rift-related extensional faults and their possible role in fluid 
(a)

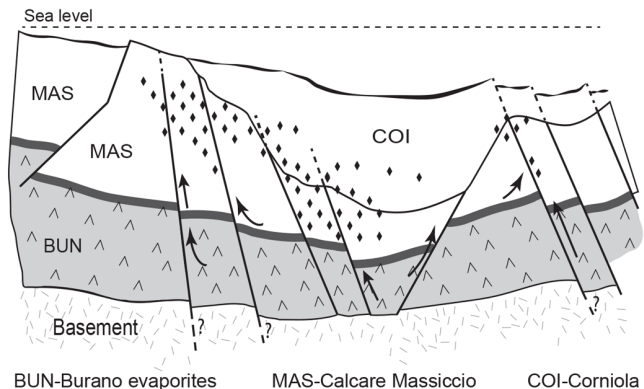

Normal faulting

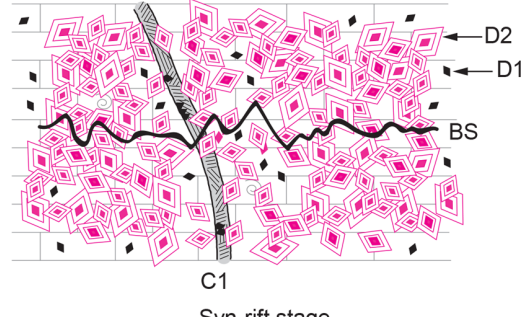

(b)

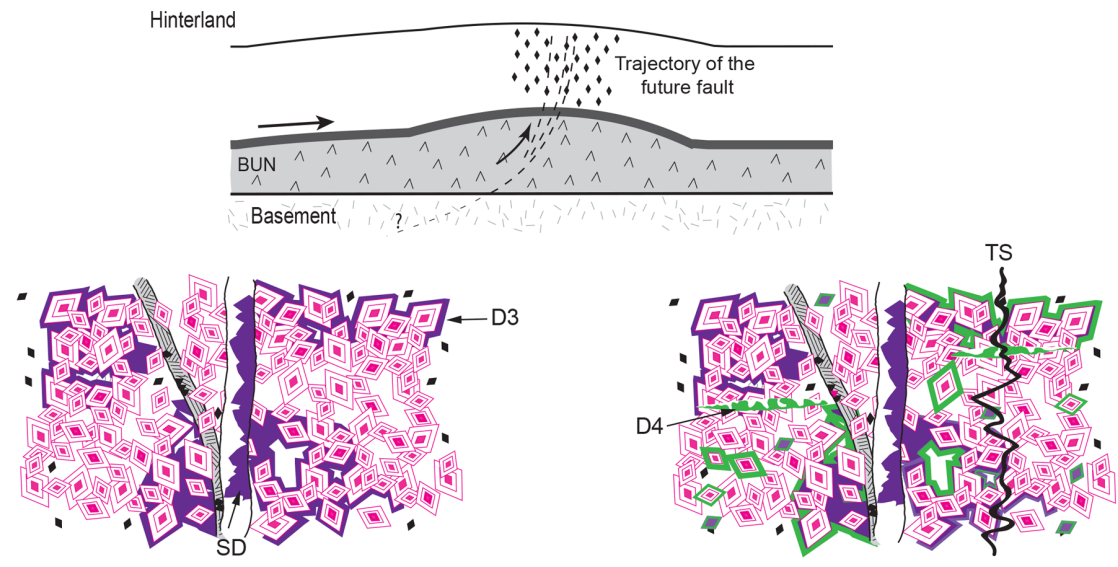

Layer parallel shortening (pre-early folding/ faulting)

(c)

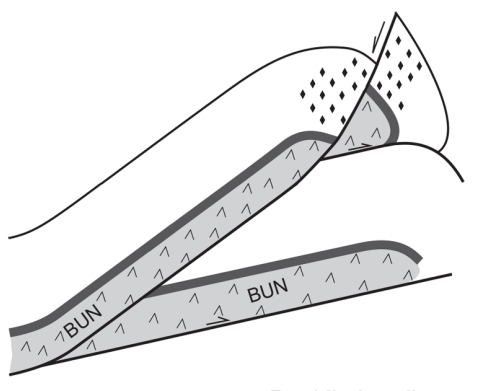

Backlimb collapse (late stage extensional faulting)

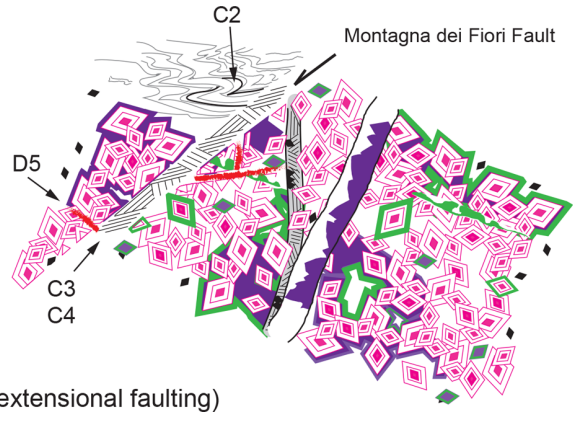

Figure 15. Sketch showing the successive fault-related diagenetic phases of most importantly dolomitization, recorded in the carbonate succession exposed at the core of the Montagna dei Fiori Anticline (not scaled). Different diagenetic phases are indicated with different colors. (a) The first dolomitization event is pre-orogenic (syn-rift), triggered from the fluids channelized along Jurassic $\sim$ E-W- and $\sim \mathrm{N}-\mathrm{S}$ striking extensional faults. This event occurred during burial compaction and development of bed-parallel stylolites (BS). It is represented by scattered dolomite rhombs (D1) followed by calcite cementation (C1). The dolomitization continued with precipitation of larger crystals of D2. (b) Second dolomitization event: syn-orogenic (early folding/faulting) dolomitization from fluids that migrated from more internal regions of the thrust belt and were channelized along the basal detachment level into the fold core. This dolomitization event presents matrix replacive and cements displaying infrequent saddle outlines (SD) in pore spaces within bed-parallel veins and shear fractures. These dolostones postdate compaction but are affected by bed-perpendicular stylolites (TS) generated by horizontal to subhorizontal layer-parallel shortening related to the growth of the Montagna dei Fiori Anticline. (c) Extensional collapse of the anticline and development of the Montagna dei Fiori Fault followed by buttressing of the Scaglia against Calcare Massiccio and Corniola formations during positive inversion induced by continuing underthrusting at depth. Precipitation of D5 in microveins and cements in breccia zones, followed by late-stage calcite cementation in the Montagna dei Fiori Fault damage zone (C2, C3, and C4). 
migration, the excess of pore pressure at the base of the thrust ramp in the fold hinge and during fold tightening could promote the localization of the fractures (Smith and Wiltschko, 1996; Ghisetti and Vezzani, 2000), with fluid migration within this zone and eventually dolomitization. These fractures could have been corridors that later on formed the incipient NW-SE Montagna dei Fiori Fault. Their localization at the back limb, cross-cutting the core, best explains the distribution of D3 and D4 at this locality. The presence of only D5 within the damage zone of the Montagna dei Fiori Fault, postdating dolostone brecciation and, in places, cementing breccia fragments, suggests that D5 dolomite precipitation was associated with the late-stage evolution of the Montagna dei Fiori Fault, predating late-stage calcite precipitation. The shift from dolomite to calcite precipitation can be ascribed to attenuation of $\mathrm{Mg}$-rich fluids and/or calcite saturation. This condition was perhaps initiated during the late stages of anticline evolution due to changes in fault conductivity sealing the upward migration of Mg-rich fluids.

The presence of several generations of bed-perpendicular stylolites bounding and intersecting $\mathrm{C} 2$ veins (Fig. 10) supports the postulation that late-stage calcite cements precipitated in close association with the deformation history of the Scaglia Formation in the hanging wall of the Montagna dei Fiori Fault (Fig. 3). This deformation occurred during buttressing against Calcare Massiccio and Corniola formations in the footwall and related to the positive inversion event induced by thrust-sheet stacking at depth (Storti et al., 2018). Precipitation of $\mathrm{C} 3$ and $\mathrm{C} 4$ is interpreted to have occurred during uplift and cooling as revealed by their relatively low homogenization temperatures $\left(\leq 40-50^{\circ} \mathrm{C}\right)$ of fluid inclusions trapped within these cements. Deformation twinning is either absent or weakly developed, reflecting the lack of significant tectonic deformation after calcite precipitation. These cements postdate the dolomitization events, high-amplitude bed-perpendicular and parallel stylolites, and are precipitated as cements bounding the breccia fragments within the damage zone of the Montagna dei Fiori Fault. Salinities calculated from their fluid inclusions, particularly in $\mathrm{C} 4$, suggests precipitation from meteoric waters, which should have been favored during the late evolutionary stages of antiformal stacking beneath the Montagna dei Fiori Anticline and eventual late extensional slip along the Montagna dei Fiori Fault (Storti et al., 2018). The results obtained in this study are in relative agreement with the earlier work by Ronchi et al. (2003) and Murgia et al. (2004) in the Central Apennines, assigning dolomitization phases to the pre- and syn-orogenic deformations, although they did not specify the direct relation between the local structures and the different types of dolomite.

The textures of the studied dolomites vary from planare to nonplanar; the preponderance of planar dolomite, as in D4, creates a rock with interesting poroperm characteristics (e.g., Woody et al., 1996; Wilson and Ruppel, 2007; Wenzhi et al., 2012). This case-study is certainly relevant for many potential reservoirs elsewhere in the world. Similar multistage burial dolomitization events enhancing the reservoir quality have been reported from the carbonate successions of the Jurassic in the Kopet Dagh Basin, north eastern Iran (Adabi, 2009), and Devonian of the Rainbow subbasin, western Canada (Qing and Mountjoy, 1989; Lonnee, 1999).

\section{Conclusions}

The Lower Jurassic limestones outcropping at the core of the Montagna dei Fiori Anticline (Central Apennines, Italy) are massively affected by dolomitization in damage zones of the pre-orogenic faults inherited from the Tethyan rifting and the ones formed during the Apenninic orogeny. Cross-cutting relationships between deformation structures, and results from optical and cold-cathode cathodoluminescence petrography, fluid inclusion microthermometry, and isotope geochemistry, support the occurrence of two major dolomitization events. The first event is interpreted as having developed during the late stages of Tethyan rifting in the Jurassic and resulted in volumetrically significant dolostone geobodies. These dolostones are largely matrix replacive and their precipitation initiated prior to the significant burial as reflected in their crosscutting relationship with bed-parallel stylolites, and by homogenization temperatures in fluid inclusions that are dominantly below about $40-50^{\circ} \mathrm{C}$. The second dolomitization event corresponds to volumetrically less relevant replacive dolomite and dolomite cements occluding fractures. These dolomites precipitated during hydrothermal fluid circulation associated with contractional tectonics during the Apenninic orogeny, possibly at the onset of the growth of the Montagna dei Fiori Anticline (Late Miocene).

Dolomitizing fluids in both events were most likely sourced from evaporitic brines associated to the underlying Burano evaporites and their interaction with siliciclastic rocks and/or the crystalline basement.

Data availability. The data used in this research are not publicly available. The data were provided based on a collaboration between Parma and KU Leuven universities.

Author contributions. MM participated in fieldwork, performed petrographic and microthermometric analyses, provided their interpretation, and wrote the article; RS participated in fieldwork, discussed the results of the diagenetic study, and critically reviewed the article; FB contributed to collect and interpret structural data, discussed structural diagenesis data interpretation, and critically reviewed the article; HED collected ${ }^{87} \mathrm{Sr} /{ }^{86} \mathrm{Sr}$ data; FS conceived the research, contributed to collect and interpret structural data, discussed structural diagenesis data interpretation, and critically reviewed the article; CT participated in fieldwork, discussed the results of the diagenetic study and their framing into the proposed structural evolution, and critically reviewed the article. 
Competing interests. The authors declare that they have no conflict of interest.

Acknowledgements. This research was performed thanks to a collaboration between Parma and KU Leuven universities in the framework of a research project (PT12432 and GFSTE 1100942) funded by Shell Global Solutions International (Carbonate Research Team, now Geology and New Reservoir Types team). We thank Enricomaria Selmo (Parma University) and Michael M. Joachimski (University of Erlangen, Germany) for the stable carbon and oxygen analysis. Gareth Davis (VU Amsterdam, the Netherlands) is thanked for the strontium isotope analysis. Andrea Comelli and Herman Nijs are kindly thanked for the careful preparation of the wafers and thin sections. Luca Barchi is gratefully appreciated for his help in SEM analysis. We acknowledge Anton Koopman for the constructive discussions during field work. We appreciate Daniel Smith (Energie Beheer Nederland, the Netherlands) for the careful reviewing of the article. We are very grateful to reviewers Jim Hendry and Estibalitz Ukar for their suggestions that allowed us to significantly improve the article.

Financial support. This research has been supported by the Shell Global Solutions International (Carbonate Research Team) (grant nos. PT12432 and GFSTE 1100942).

Review statement. This paper was edited by Elias Samankassou and reviewed by Jim Hendry and Estibalitz Ukar.

\section{References}

Adabi, M. H.: Multistage dolomitization of upper jurassic mozduran formation, Kopet-Dagh Basin, NE Iran, Carbonate. Evaporite., 24, 16-32, https://doi.org/10.1007/BF03228054, 2009.

Alvarez, W.: Evolution of the Monte Nerone Seamount in the Umbria-Marches Apennines; I, Jurassic-Tertiary stratigraphy, B. Soc. Geol. Ital., 108, 3-21, 1989.

Amieux, P.: La cathodoluminescence: méthode d'étude sédimentologique des carbonates, B. Cent. Rech. Expl., 6, 437-483, 1982.

Artoni, A.: Messinian events within the tectono-stratigraphic evolution of the Southern Laga Basin (Central Apennines, Italy), B. Soc. Geol. Ital., 122, 447-466, 2003.

Artoni, A.: The Pliocene-Pleistocene stratigraphic and tectonic evolution of the central sector of the Western Periadriatic Basin of Italy, Mar. Petrol. Geol., 42, 82-106, https://doi.org/10.1016/j.marpetgeo.2012.10.005, 2013.

Banner, J. L.: Radiogenic isotopes: systematics and applications to earth surface processes and chemical stratigraphy, Earth. Sci. Rev., 65, 141-194, https://doi.org/10.1016/S00128252(03)00086-2, 2004.

Barchi, M., Minelli, G., and Pialli G.: The CROP 03 profile: a synthesis of results of deep structures of the Northern Apennines, Mem. Soc. Geol. It., 52, 383-400, 1998.

Barker, S. L. and Cox, S. F.: Evolution of fluid chemistry and fluidflow pathways during folding and faulting: an example from Tae- mas, NSW, Australia, Geol. Soc. London Spec. Publ., 359, 203 227, https://doi.org/10.1144/SP359.12, 2011.

Bassetti, M. A., Ricci Lucchi, F., Roveri, M., and Taviani, M.: Messinian facies in a critical section of northern Apennines (Montepetra-Perticara, Pesaro), Giorn. Geol., 60, 261-263, 1998.

Bistacchi, A., Balsamo, F., Storti, F., Mozafari, M., Swennen, R., Solum, J., Tueckmantel, C., and Taberner, C.: Photogrammetric digital outcrop reconstruction, visualization with textured surfaces, and three-dimensional structural analysis and modeling: Innovative methodologies applied to fault-related dolomitization (Vajont Limestone, Southern Alps, Italy), Geosphere, 11, 2031 2048, https://doi.org/10.1130/GES01005.1, 2015.

Bathurst, R. G. C.: Deep crustal diagenesis in limestones: Revista del Instituto de Investigaciones Geologicas, Deputacion Provincial, Universidad Barcelona, 34, 89-100, 1980.

Bernoulli, D., Kälin, O., and Patacca, E.: A sunken continental margin of the Mesozoic Tethys: The Northern and Central Apennines, Symposium Sédimentation jurassique W Européen, Spec. Publ. Ass. Sedim. Francis, 1, 179-210, 1979.

Bodnar, R. J.: Revised equation and table for determining the freezing point depression of $\mathrm{H}_{2} \mathrm{O}-\mathrm{NaCl}$ solutions, Geochim. Cosmochim. Ac., 57, 683-684, https://doi.org/10.1016/00167037(93)90378-A, 1993.

Boles, J. R. and Franks, S. G.: Clay diagenesis in Wilcox Sandstone of southwest Texas: Implications of smectite diagenesis and sandstone cementation, J. Sediment. Petrol., 49, 55-70, https://doi.org/10.1306/212F76BC-2B24-11D78648000102C1865D, 1979.

Bollati, A., Corrado, S., and Marino, M.: Inheritance of Jurassic rifted margin architecture into the Apennines Neogene mountain building: a case history from the Lucretili Mts. (Latium, Central Italy), Int. J. Earth Sci., 101, 1011-1031, https://doi.org/10.1007/s00531-011-0694-7, 2012.

Bosence, D., Procter, E., Aurell, M., Kahla, A. B., BoudagherFadel, M., Casaglia, F., Cirilli, S., Mehdie, M., Nieto, L., Rey, J., Scherreiks, R., Soussi, M., and Waltham, D.: A dominant tectonic signal in high-frequency, peritidal carbonate cycles? A regional analysis of Liassic platforms from western Tethys, J. Sediment. Res., 79, 389-415, https://doi.org/10.2110/jsr.2009.038, 2009.

Boschetti, T., Venturelli, G., Toscani, L., Barbieri, M., and Mucchino, C.: The Bagni di Lucca thermal waters (Tuscany, Italy): an example of $\mathrm{CaSO}_{4}$ waters with high $\mathrm{Na} / \mathrm{Cl}$ and low $\mathrm{Ca} / \mathrm{SO}_{4}$ ratios, J. Hydrol., 307, 270-293, https://doi.org/10.1016/j.jhydrol.2004.10.015, 2005.

Brandano, M., Cornacchia, I., Raffi, I., and Tomassetti, L.: The Oligocene-Miocene stratigraphic evolution of the Majella carbonate platform (Central Apennines, Italy), Sediment. Geol., 333, 1-14, https://doi.org/10.1016/j.sedgeo.2015.12.002, 2016.

Burke, W. H., Denison, R. E., Hetherington, E. A., Koepnick, R. B., Nelson, H. F., and Otto, J. B.: Variation of seawater ${ }^{87} \mathrm{Sr} /{ }^{86} \mathrm{Sr}$ throughout Phanerozoic time, Geology, 10, 516-519, https://doi.org/10.1130/00917613(1982)10<516:VOSSTP>2.0.CO;2, 1982.

Burkhard, M.: Calcite twins, their geometry, appearance and significance as stress-strain markers and indicators of tectonic regime: a review, J. Struct. Geol., 15, 351-368, https://doi.org/10.1016/0191-8141(93)90132-T, 1993. 
Calamita, F., Cello, G., Deiana, G., and Paltrinieri, W.: Structural styles, chronology rates of deformation, and time-space relationships in the Umbria-Marche thrust system (central Apennines, Italy), Tectonics, 13, 873-881, https://doi.org/10.1029/94TC00276, 1994.

Cardello, G. L. and Doglioni, C.: From mesozoic rifting to Apennine orogeny: the gran Sasso range (Italy), Gondwana Res., 27, 1307-1334, https://doi.org/10.1016/j.gr.2014.09.009, 2015.

Carpenter, B.: Origin and chemical evolution of brines in sedimentary basins, Oklahoma Geol. Surv., 79, 60-77, https://doi.org/10.2118/7504-MS, 1978.

Centamore, E., Chiocchini, U., and Moretti, A.. Geologia della zona tra Acerenza e Avigliano (Prov. di Potenza), Studi Geol. Camerti, 1, 97-122, https://doi.org/10.15165/studgeocam-1462, 1971.

Chilovi, C., De Feyter, A. J., Minelli, G., and Barchi, M. R.. Neogene strike-slip reactivation of Jurassic normal faults in the M. Nerone-M. Catria Anticline (Umbro-Marchean Apennines, Italy), Boll. Soc. Geol. Ital., 121, 199-207, 2002.

Clemenzi, L., Storti, F., Balsamo, F., Molli, G., Ellam, R., Muchez, P., and Swennen, R.: Fluid pressure cycles, variations in permeability, and weakening mechanisms along low-angle normal faults: The Tellaro detachment, Italy, Am. Assoc. Petr. Geol. B., 127, 1689-1710, https://doi.org/10.1130/B31203.1, 2015.

Colacicchi, R., Passeri, L., and Pialli, G.: Evidences of tidal environment deposition in the Calcare Massiccio formation (Central Apennines-Lower Lias), in: Tidal Deposits, edited by: Ginsburg, R. N., Springer, Berlin, Heidelberg, Germany, 345-353, https://doi.org/10.1007/978-3-642-88494-8, 1975.

Cooper, J. C. and Burbi, L.: The geology of the central Sibillini Mountains, Mem. Soc. Geol. It., 35, 323-347, 1986.

Crescenti, U.: Serie stratigrafiche della serie calcarea dal Lias al Miocene nella regione Marchigiano Abruzzese: parte I and II, Mem. Soc. Geol. It., 8, 155-420, 1969.

Davies, G. R. and Smith, L. B. J.: Structurally controlled hydrothermal dolomite reservoir facies: an overview, Am. Assoc. Petr. Geol. B., 90, 1641-1690, 2006.

Del Moro, A., Puxeddu, M., Radicati di Brozolo, F., and Villa, I. M.: Rb-Sr and K-Ar ages of minerals at temperatures of $300-400^{\circ} \mathrm{C}$ from deep wells in the Larderello geothermal field (Italy), Contrib. Mineral. Petr., 81, 349-349, https://doi.org/10.1007/BF00371688, 1982.

Dewey, J. F., Helman, M. L., Turco, E., Hutton, D. H. W., and Knott, S. D.: Kinematics of the western Mediterranean, in: Alpine Tectonics, edited by: Coward, M. P., Dietrich, D., and Park, R. G., Geol. Soc. London Spec. Publ., 45, 265-283, https://doi.org/10.1144/GSL.SP.1989.045.01.15, 1989.

Dewit, J., Foubert, A., El Desouky, H. A., Muchez, P., Hunt, D., Vanhaecke, F., and Swennen, R.: Characteristics, genesis and parameters controlling the development of a large stratabound HTD body at Matienzo (Ramales Platform, BasqueCantabrian Basin, northern Spain), Mar. Petrol. Geol., 55, 6-25, https://doi.org/10.1016/j.marpetgeo.2013.12.021, 2014.

Dickson, J. A. D.: Carbonate identification and genesis as revealed by staining, J. Sediment. Petrol., 36, 491-505, https://doi.org/10.1306/74D714F6-2B21-11D78648000102C1865D, 1966.

Di Francesco, L., Fabbi, S., Santantonio, M., Bigi, S., and Poblet, J.: Contribution of different kinematic models and a complex Jurassic stratigraphy in the construction of a forward model for the
Montagna dei Fiori fault-related fold (Central Apennines, Italy), Geol. J., 45, 489-505, https://doi.org/10.1002/gj.1191, 2010.

Eichhubl, P. and Boles, J. R.: Rates of fluid flow in fault systems; evidence for episodic rapid fluid flow in the Miocene Monterey Formation, coastal California, Am. J. Sci., 300, 571-600, https://doi.org/10.2475/ajs.300.7.571, 2000.

Elter, P., Giglia, G., Tongiorgi, M., and Trevisan, L.: Tensional and contractional areas in the recent (Tortonian to Present) evolution of the Northern Apennines, B. Geofis. Teor. Appl., 17, 3-18, 1975.

Emery, D. and Robinson, A. (Eds.): Inorganic Geochemistry: Applications to Petroleum Geology, Blackwell Science, Oxford, UK, 101-128, 1993.

Fantoni, R. and Franciosi, R.: Tectono-sedimentary setting of the Po Plain and Adriatic foreland, Rend. Lincei, 21, 197-209, https://doi.org/10.1007/s12210-010-0102-4, 2010.

Ferraro, F., Agosta, F., Ukar, E., Grieco, D. S., Cavalcante, F., Belviso, C., and Prosser, G.: Structural diagenesis of carbonate fault rocks exhumed from shallow crustal depths: An example from the central-southern Apennines, Italy, J. Struct. Geol., 122, 58-80, https://doi.org/10.1016/j.jsg.2019.02.008, 2019.

Friedman, I.: Some investigations of the deposition of travertine from Hot Springs-I. The isotopic chemistry of a travertinedepositing spring, Geochim. Cosmochim. Ac., 34, 1303-1315, https://doi.org/10.1016/0016-7037(70)90043-8, 1970.

Gale, J. F., Laubach, S. E., Marrett, R. A., Olson, J. E., Holder, J., and Reed, R. M.: Predicting and characterizing fractures in dolostone reservoirs: Using the link between diagenesis and fracturing, Geol. Soc. London Spec. Publ., 235, 177-192, https://doi.org/10.1144/GSL.SP.2004.235.01.08, 2004.

Ghisetti, F. and Vezzani, L.: Interfering paths of deformation and development of arcs in the fold-and-thrust belt of the central Apennines (Italy), Tectonics, 16, 523-536, https://doi.org/10.1029/97TC00117, 1997.

Ghisetti, F. and Vezzani, L.: Detachments and normal faulting in the Marche fold-and-thrust belt (Central Apennines, Italy): inferences on fluid migration paths, J. Geodyn., 29, 345-369, https://doi.org/10.1016/S0264-3707(99)00057-5, 2000.

Giacometti, A. and Ronchi, P.: Early Lias Carbonate Platform: Facies and Diagenesis Analogies between the Calcare Massiccio (Umbro-Marchean Apennines) and the Inici Fm. (Sicily Channel), Mem. Soc. Geol. It., 55, 271-278, 2000.

Goldstein, R. H.: Petrographic and geochemical evidence for origin of paleospeleothems, New Mexico: Implications for the application of fluid inclusions to studies of diagenesis, J. Sediment. Petrol., 60, 282-292, https://doi.org/10.1306/212F91742B24-11D7-8648000102C1865D, 1990.

Goldstein, R. H. and Reynolds, T. J.: Systematics of Fluid Inclusions in Diagenetic Minerals, Soc. Sediment. Geol., 31, 199 pp., 1994.

Habermann, D., Meijer, J., Neuser, R. D., Richter, D. K., Rolfs, C., and Stephan, A.: Micro-PIXE and quantitative cathodolumin- escence spectroscopy: combined high resolution trace element analyses in minerals, Nuclear Instruments and Methods in Physics Research Section B, 150, 470-477, https://doi.org/10.1016/S0168-583X(98)00926-4, 1999.

Hendry, J. P., Gregg, J. M., Shelton, K. L., Somerville, I. D., and Crowley, S. F.: Origin, characteristics and distribution of faultrelated and fracture-related dolomitization: Insights from Mis- 
sissippian carbonates, Isle of Man, Sedimentology, 62, 717-752, https://doi.org/10.1111/sed.12160, 2015.

Hiemstra, E. J. and Goldstein, R. H.: Repeated injection of hydrothermal fluids into downdip carbonates: a diagenetic and stratigraphic mechanism for localization of reservoir porosity, Indian Basin Field, New Mexico, USA, Geol. Soc. London Spec. Publ., 406, 141-177, https://doi.org/10.1144/SP406.1, 2015.

Hollis, C., Bastesen, E., Boyce, A., Corlett, H., Gawthorpe, R., Hirani, J. Rotevatn, A., and Whitaker, F.: Fault-controlled dolomitization in a rift basin, Geology, 45, 219-222, https://doi.org/10.1130/G38s394.1, 2017.

Horita, J.: Oxygen and carbon isotope fractionation in the system dolomite-water-CO2 to elevated temperatures, Geochim. Cosmochim. Ac., 129, 111-124, https://doi.org/10.1016/j.gca.2013.12.027, 2014.

Hudson, J. D.: Stable isotopes and limestone lithification, Geol. Soc. London, 133, 637-660, https://doi.org/10.1144/gsjgs.133.6.0637, 1977.

Koopman, A.: Detachment tectonics in the central Apennines, Italy, PhD thesis, Utrecht University, the Netherlands, 155 pp., 1983.

Land, L. S.: The isotopic and trace element geochemistry of dolomite: the state of the art, in: Concepts and Models of dolomitization, edited by: Zenger D. H., Dunham J. B., and Ethington R. L., Soc. Econ. Paleontol. Mineral., Spec. Pub., 28, 87-110, 1980.

Land, L. S.: The application of stable isotopes to studies of the origin of dolomite and to problems of diagenesis of clastic sediments, in: Stable Isotopes in Sedimentary Geology, edited by: Arthur M. A., Soc. Econ. Paleontol. Mineral., 10, 4-1, 1983.

Land, L. S.: The origin of massive dolomite, J. Geol. Educ., 33, 112-125, 1985.

Laubach, S. E., Eichhubl, P., Hilgers, C., and Lander, R. H.: Structural diagenesis, J. Struct. Geol., 32, 1866-1872, https://doi.org/10.1016/j.jsg.2010.10.001, 2010.

Li, Z., Goldstein, R. H., and Franseen, E. K.: Meteoric calcite cementation: diagenetic response to relative fall in sealevel and effect on porosity and permeability, Las Negras area, southeastern Spain, Sediment. Geol., 348, 1-18, https://doi.org/10.1016/j.sedgeo.2016.12.002, 2017

Lind, I. L., Berger, W. H., and Kroenke, L. W.: Stylolites in chalk from leg 130, Ontong Java Plateau, Proceedings of the Ocean Drilling Program, Scientific Results, 445-451, 1993.

Lobato, L. M., Forman, J. M. A., Fazikawa, K., Fyfe, W. S., and Kerrich, R.: Uranium in overthrust Archean basement, Bahia, Brazil, Can. Mineral., 21, 647-654, 1983.

Lonnee, J. S.: Sedimentology, dolomitization and diagenetic fluid evolution of the Middle Devonian Sulphur Point Formation, northwestern Alberta, $\mathrm{PhD}$ thesis, University of Windsor, Canada, 133 pp., 1999.

Luczaj, J. A. and Goldstein, R. H.: Diagenesis of the Lower Permian Krider Member, southwest Kansas, USA: fluidinclusion, U-Pb, and fission-track evidence for reflux dolomitization during latest Permian time, J. Sediment. Res., 70, 762-773, https://doi.org/10.1306/2DC40936-0E47-11D78643000102C1865D, 2000.

Machel, H. G.: Effects of groundwater flow on mineral diagenesis, with emphasis on carbonate aquifers, Hydrol. J., 7, 94-107, https://doi.org/10.1007/s100400050182, 1999.
Machel, H. G. and Cavell, P. A.: Low-flux, tectonically-induced squeegee fluid flow, B. Can. Petrol. Geol., 47, 510-533, 1999.

Machel, H. G., Mason, R. A., Mariano, A. N., and Mucci, A.: Causes and emission of luminescence in calcite and dolomite, in: Luminescence microscopy and spectroscopy: Qualitative and quantitative applications, edited by: Barker, C. E. and Kopp, O. C., Soc. Sediment. Geol., 25, 9-25, 1991.

Major, R. P., Lloyd, R. M., and Lucia, F. J.: Oxygen isotope composition of Holocene dolomite formed in a humid hypersaline setting, Geology, 20, 586-588, https://doi.org/10.1130/00917613(1992)020<0586:OICOHD>2.3.CO;2, 1992.

Marino, M. and Santantonio, M.: Understanding the geological record of carbonate platform drowning across rifted Tethyan margins: Examples from the Lower Jurassic of the Apennines and Sicily (Italy), Sediment. Geol., 225, 116-137, https://doi.org/10.1016/j.sedgeo.2010.02.002, 2010.

Marshall, J. D.: Climatic and oceanographic isotopic signals from the carbonate rock record and their preservation, Geol. Mag., 129, 143-160, https://doi.org/10.1017/S0016756800008244, 1992.

Mattei, M.: Analisi geologico-strutturale della Montagna dei Fiori (Ascoli Piceno, Italia Centrale), Geol. Romana, 26, 327-347, 1987.

Mazzoli, S., Deiana, G., Galdenzi, S., and Cello, G.: Miocene faultcontrolled sedimentation and thrust propagation in the previously faulted external zones of the Umbria-Marche Apennines, Italy, EGU Stephan Mueller Spec. Publ. Ser., 1, 195-209, 2002.

Mazzullo, S. J.: Geochemical and neomorphic alteration of dolomite: a review, Carbonates Evaporites, 7, 21-37, https://doi.org/10.1007/BF03175390, 1992.

McArthur, J. M., Howarth, R. J., and Shields, G. A.: Strontium isotope stratigraphy, in: The Geologic Time Scale 2012, edited by: Gradstein, F. M., Ogg, J. G., Schmitz, M., and Ogg, G., Elsevier, 127-144, https://doi.org/10.1016/C2011-1-08249-8, 2012.

McCaffrey, M. A., Lazar, B., and Holland, H. D.: The evaporation path of seawater and the coprecipitation of $\mathrm{Br}-$ and $\mathrm{Kp}$ with halite, J. Sediment. Res., 57, 928937, https://doi.org/10.1306/212F8CAB-2B24-11D78648000102C1865D, 1987.

McCaig, A. M.: Deep fluid circulation in fault zones, Geology, 16, 867-870, https://doi.org/10.1130/00917613(1988)016<0867:DFCIFZ>2.3.CO;2, 1988.

McCaig, A. M., Wickham, S. M., and Taylor, H. P.: Deep fluid circulation in alpine shear zones, Pyrenees, France: field and oxygen isotope studies, Contrib. Mineral. Petr., 106, 41-60, https://doi.org/10.1007/BF00306407, 1990.

Montanez, I. P.: Late diagenetic dolomitization of Lower Ordovician, upper Knox carbonates: A record of the hydrodynamic evolution of the southern Appalachian Basin, Am. Assoc. Petr. Geol. B., 78, 1210-1239, 1994.

Moore, C. H. (Ed.): Carbonate diagenesis and porosity, Dev. Sedimentol., 46, Elsevier Sci. Publ., Amsterdam, the Netherlands, 338 pp., 1989.

Morettini, E., Santantonio, M., Bartolini, A., Cecca, F., Baumgartner, P. O., and Hunziker, J. C.: Carbon isotope stratigraphy and carbonate production during the Early-Middle Jurassic: examples from the Umbria-Marche-Sabina Apennines (central Italy), Palaeogeogr. Palaeocl., 184, 251-273, https://doi.org/10.1016/S0031-0182(02)00258-4, 2002. 
Mountjoy, E. W., Machel, H. G., Green, D., Duggan, J., and Williams-Jones, A. E.: Devonian matrix dolomites and deep burial carbonate cements: a comparison between the RimbeyMeadowbrook reef trend and the deep basin of west-central Alberta, B. Can. Petrol. Geol., 47, 487-509, 1999.

Murgia, M. V., Ronchi, P., and Ceriani, A.: Dolomitization processes and their relationships with the evolution of an orogenic belt (Central Apennines and peri-adriatic foreland, Italy), AAPG Hedberg series, 1, 277-294, https://doi.org/10.1306/1025695H13121, 2004.

Nelson, R. A: Significance of fracture sets associated with stylolite zones, Am. Assoc. Petr. Geol. B., 65, 2417-2425, 1981.

Parotto, M. and Praturlon, A.: Geological summary of the Central Apennines, Quad. Ric. Sci., 90, 257-311, 1975.

Patacca, E., Sartori, R., and Scandone, P.: Tyrrhenian basin and Apenninic arcs: Kinematic relations since late Tortonian times, Mem. Soc. Geol. It., 45, 425-451,1992.

Pialli, G.: Facies di piana cotidale nel Calcare Massiccio dell'Appennino umbro marchigiano, Boll. Soc. Geol. It., 90, 481-507, 1971.

Pierantoni, P., Deiana, G., and Galdenzi, S.: Stratigraphic and structural features of the Sibillini Mountains (UmbriaMarche Apennines, Italy), Ital. J. Geosci., 132, 497-520, https://doi.org/10.3301/IJG.2013.08, 2013.

Purser, B., Tucker, M., and Zenger, D.: Problems, progress and future research concerning dolomites and dolomitization, in: Dolomites: a Volume in Honour of Dolomieu, edited by: Purser, B., Tucker, M., and Zenger, D., IAS Spec. Publ., 21, 3-20, 1994.

Qing, H. and Mountjoy, E. W.: Multistage dolomitization in Rainbow buildups, Middle Devonian Keg River Formation, Alberta, Can. J. Sediment. Res., 59, 114-126, https://doi.org/10.1306/212F8F30-2B24-11D78648000102C1865D, 1989.

Radke, B. M. and Mathis, R. L.: On the formation and occurrence of saddle dolomite, J. Sediment. Res., 50, 1149-1168, https://doi.org/10.1306/212F7B9E-2B24-11D78648000102C1865D, 1980.

Ronchi, P., Casaglia, F., and Ceriani, A.: The multiphase dolomitization of the Liassic Calcare Massiccio and Corniola successions (Montagna dei Fiori, Northern Apennines, Italy), Boll. Soc. Geol. It., 122, 157-172, 2003.

Rosenbaum, J. and Sheppard, S. M.: An isotopic study of siderites, dolomites, and ankerites at high temperatures, Geochim. Cosmochim. Ac., 50, 1147-1150, https://doi.org/10.1016/00167037(86)90396-0, 1986.

Roveri, M., Bassetti, M. A., and Lucchi, F. R.: The Mediterranean Messinian salinity crisis: an Apennine foredeep perspective, Sediment. Geol., 140, 201-214, https://doi.org/10.1016/S00370738(00)00183-4, 2001.

Saelen, G., Doyle, P., and Talbot, M. R.: Stable-isotope analyses of belemnite rostra from the Whitby Mudstone Fm., England: Surface water conditions during deposition of a marine black shale, Palaios, 11, 97-117, https://doi.org/10.2307/3515065, 1996.

Santantonio, M. and Carminati, E.: Jurassic rifting evolution of the Apennines and Southern Alps (Italy): Parallels and differences, Geol. Soc. Am. B., 123, 464-484, https://doi.org/10.1130/B30104.1, 2011.

Schulz, H. M., Wirth, R., and Schreiber, A.: Organic-inorganic rock-fluid interactions in stylolitic micro-environments of car- bonate rocks: a FIB-TEM study combined with a hydrogeochemical modelling approach, Geofluids, 16, 909-924, https://doi.org/10.1111/gfl.12195, 2016.

Scisciani V., Tavarnelli, E., and Calamita, F.: The interaction of extensional and contractional deformations in the outer zones of the Central Apennines, Italy, J. Struct. Geol., 24, 1647-1658, https://doi.org/10.1016/S0191-8141(01)00164-X, 2002.

Shackleton, N. J. and Kennett, J. P.: Paleotemperature History of the Cenozoic and the Initiation of Antartic Glaciation Oxygen and Carbon Isotope Analyses in DSDP Sites 277, 279, and 281, Initial reports of Deep Sea Drilling Project, 29, 743-755, 1975.

Sharp, I., Gillespie, P., Morsalnezhad, D., Taberner, C., Karpuz, R., Vergés, J., Horbury, A., Pickard, N., J. Garland, J., and Hunt, D.: Stratigraphic architecture and fracture-controlled dolomitization of the Cretaceous Khami and Bangestan groups: an outcrop case study, Zagros Mountains, Iran, Geol. Soc. London Spec. Publ., 329, 343-396, https://doi.org/10.1144/SP329.14, 2010.

Shepherd, T., Rankin, A. H., and Alderton, D. H. M. (Eds.): A Practical Guide to Fluid Inclusion Studies, Glasgow, Blackie, 239 pp., 1985.

Sibley, D. F. and Gregg, J. M.: Classification of dolomite rock textures, J. Sediment. Petrol., 57, 967975, https://doi.org/10.1306/212F8CBA-2B24-11D78648000102C1865D, 1987.

Sibson, R. H.: Fluid flow accompanying faulting: field evidence and models, Earthquake prediction: an international review, AGU, 4, 593-603, https://doi.org/10.1029/ME004p0593, 1981.

Slobodník, M., Muchez, P., Kral, J., and Keppens, E.: Variscan veins: record of fluid circulation and Variscan tectonothermal events in Upper Palaeozoic limestones of the Moravian Karst, Czech Republic, Geol. Mag., 143, 491-508, https://doi.org/10.1017/S0016756806001981, 2006.

Smith, R. E. and Wiltschko, D. V.: Generation and maintenance of abnormal fluid pressures beneath a ramping thrust sheet: isotropic permeability experiments, J. Struct. Geol., 18, 951-970, https://doi.org/10.1016/0191-8141(96)00023-5, 1996.

Sommer, S. E.: Cathodoluminescence of carbonates, 1. Characterization of cathodoluminescence from carbonate solid solutions, Chem. Geol., 9, 257-273, https://doi.org/10.1016/00092541(72)90064-2, 1972.

Steiger, R. and Jäger, E.: Subcommission on geochronology: convention on the use of decay constants in geo and cosmochronology, Earth Planet. Sc. Lett., 36, 359-362, https://doi.org/10.1016/0012-821X(77)90060-7, 1977.

Storti, F., Balsamo, F., and Koopman, A.: Geological map of the partially dolomitized Jurassic succession exposed in the core of the Montagna dei Fiori Anticline, Central Apennines, Italy, Ital. J. Geosci., 136, 125-135, https://doi.org/10.3301/IJG.2016.05, 2017a.

Storti F., Balsamo, F., and Koopman, A.: Reply to: discussion on "Geological map of the partially dolomitized Jurassic succession exposed in the central sector of the Montagna dei Fiori Anticline, Central Apennines, Italy" by Santantonio, M., Fabbi, S. and Bigi, S., Ital. J. Geosci., 136, 317-319, https://doi.org/10.3301/IJG.2017.04, 2017b.

Storti, F., Balsamo F., Mozafari M., Koopman A., Swennen R., and Taberner C.: Syn-contractional overprinting between extension and shortening along the Montagna dei Fiori Fault during Plio-Pleistocene antiformal stacking at the 
Central Apennines thrust wedge toe, Tectonics, 37, 1-31, https://doi.org/10.1029/2018TC005072, 2018.

Stueber, A. M., Pushkar, P., and Baldwin, A. D., JR.: Survey of ${ }^{87} \mathrm{Sr} /{ }^{86} \mathrm{Sr}$ ratios and total strontium concentrations in Ohio stream and ground waters, Ohio J. Sci., 72, 98-104, 1972.

Swennen, R., Dewit, J., Fierens, E., Muchez, Ph., Shah, M., Nader, F. H., and Hunt, D.: Multiple dolomitisation events along the Ranero fault (Pozalagua Quarry, BasqueeCantabrian Basin): episodic earthquake activity, Sedimentology, 59, 1345-1374, https://doi.org/10.1111/j.1365-3091.2011.01309.x, 2012.

Tavani, S., Storti, F., Salvini, F., and Toscano, C.: Stratigraphic versus structural control on the deformation pattern associated with the evolution of the Mt. Catria anticline, Italy, J. Struct. Geol., 30, 664-681, https://doi.org/10.1016/j.jsg.2008.01.011, 2008.

Taylor, H. P.: Oxygen and hydrogen isotope relationships in hydrothermal mineral deposits, in: Geochemistry of hydrothermal ore deposits, edited by: Barnes, H. L., Wiley and Sons, New York, 229-302, 1997.

Thirlwall, M. F.: Long-term reproducibility of multicollector $\mathrm{Sr}$ and $\mathrm{Nd}$ isotope ratio analysis, Chem. Geol., 94, 85-104, https://doi.org/10.1016/S0009-2541(10)80021-X, 1991.

Tongiorgi, M., Rau, A., and Martini, I. P.: Sedimentology of early-alpine, fluvio-marine, clastic deposits (Verrucano, Triassic) in the Monti Pisani (Italy), Sediment. Geol., 17, 311-332, https://doi.org/10.1016/0037-0738(77)90051-3, 1977.

Ukar, E. and Laubach, S. E.: Syn-and postkinematic cement textures in fractured carbonate rocks: Insights from advanced cathodoluminescence imaging, Tectonophysics, 690, 190-205, https://doi.org/10.1016/j.tecto.2016.05.001, 2016.

Vai, G. B. and Ricci Lucchi, F.: Algal crusts, autochthonous and clastic gypsum in a cannibalistic evaporite basin: a case history from the Messinian of northern Apennines, Sedimentology, 24, 221-244, https://doi.org/10.1111/j.13653091.1977.tb00255.x, 1977.

Vandeginste, V., Swennen, R., Gleeson, S. A., Ellam, R. M., Osadetz, K., and Roure, F.: Zebra dolomitization as a result of focused fluid flow in the Rocky Mountains Fold and Thrust Belt, Canada, Sedimentology, 52, 1067-1095, https://doi.org/10.1111/j.1365-3091.2005.00724.x, 2005.
Veizer, J., Ala, D., Azmy, K., Bruckshen, P., Buhl, D., Bruhn, F., Carden, G. A. F., Diener, A., Ebneth, S., Godderis, Y., Jasper, T., Korte, C., Pawellek, F., Podlaha, O. G., and Strauss, H.: ${ }^{87} \mathrm{Sr} /{ }^{86} \mathrm{Sr}, \quad \delta^{13} \mathrm{C}$ and evolution of Phanerozoic seawater, Chem. Geol., 161, 59-88, https://doi.org/10.1016/S00092541(99)00081-9, 1999.

Walker, G., Abumere, O. E., and Kamaluddin, B.: Luminescence spectroscopy of Mn2 rock-forming carbonates, Mineral. Mag., 53, 201-11, 10.1180/minmag.1989.053.370.07, 1989.

Wenzhi, Z., Anjiang, S., Suyun, H., Baomin, Z., Wenqing, P., Jingao, Z., and Zecheng, W.: Geological conditions and distributional features of large-scale carbonate reservoirs onshore China, Petrol. Explor. Dev., 39, 1-14, https://doi.org/10.1016/S18763804(12)60010-X, 2012.

Wilson, A. and Ruppel, C.: Salt tectonics and shallow subsea floor fluid convection: models of coupled fluid-heat-salt transport, Geofluids, 7, 377-386, https://doi.org/10.1111/j.14688123.2007.00191.x, 2007.

Wilson, M. E. J., Evans, M. J., Oxtoby, N. H., Nas, D. S., Donnelly, T., and Thirlwall, M.: Reservoir quality, textural evolution, and origin of fault-associated dolomites, AAPB Bull., 91, 1247$1272,2007$.

Woodcock, N. H. and Mort, K.: Classification of fault breccias and related fault rocks, Geol. Mag., 145, 435-440, https://doi.org/10.1017/S0016756808004883, 2008.

Woody, R. E., Gregg, J. M., and Koederitz, L. F.: Effect of texture on petrophysical properties of dolomite: Evidence from the Cambrian-Ordovician of Southeastern Missouri, AAPG Bull., 80, 119-131, 1996.

Zempolich, W. G. and Hardie, L. A.: Geometry of dolomite bodies within deep-water resedimented oolite of the Middle Jurassic Vajont Limestone, Venetian Alps, Italy: Analogs for hydrocarbon reservoirs created through fault-related burial dolomitization, in: Reservoir quality prediction in sandstones and carbonates, edited by: Kupecz, A., Gluyas, J., and Bloch, S., AAPG Memoir., 69, 127-162, 1997. 